\title{
Archaeological Practice in the Inter-War Years
}

\begin{abstract}
By the courtesy of the contractors and the officials of the Co-operative Society the writer has been privileged to watch the progress of the excavations, and during brief daily visits, to recover from the sludge, before it was carted away, a representative collection of objects and other interesting relics of mediceval days (Armstrong 1927b)
\end{abstract}

The rediscovery of Sheffield Castle commenced in earnest in 1927, with the construction of the new city-centre store of the Brightside and Carbrook Co-operative Society and (shortly afterwards) of Sheffield Corporation's Castle Hill Market just to the north. The paper Leslie Armstrong published in the Transactions of the Hunter Archaeological Society in 1930 was based on observations made during this construction work. This seminal paper has been the principal source for all subsequent understanding of Sheffield Castle (e.g. Walton 1949, 21-2; Fine 2003, 36, 41; Jones 2004, 27; Hey 2010, 15; Hallam 2015) but has been subject to little critical scrutiny, and few have considered the inevitable shortcomings of efforts to record the remains of the castle in the pressurised circumstances of commercial construction. Nor has the role and influence of Armstrong's collaborator Joseph Himsworth been adequately assessed or, indeed, acknowledged. In this chapter we use unpublished sources in the Museums Sheffield archive including correspondence, diaries, lecture notes and excavation records, as well as contemporary newspaper articles, to situate Armstrong and Himsworth's work (both on site and in publication) in the context of the personalities involved, the prevailing intellectual climate, archaeological practice, and understandings of the past and of its value in contemporary society. In this first part of the story of the uncovering of Sheffield Castle, it is the amateur enthusiasts, local heroes battling against the odds, who take centre stage, the man from the Inland Revenue supported, aptly for Sheffield, by the son of a cutler. In their work we see a narrative emerging around the castle, we feel the excitement and thrill of discovery that shines through the manuscript sources - and the myth making commences.

\section{Sheffield Castle: where the two rivers meet}

In his 1930 publication Leslie Armstrong gives a laconic account of the circumstances leading up to the first 20th-century archaeological investigation of Castle Hill. He reports that in $1915^{1}$ the Brightside and Carbrook Co-op bought part of the site with the intention of building a new city-centre store. Construction began

${ }^{1}$ Other sources say that the Co-op purchased the site in 1914 (Denton 1946; English Heritage 2009).

How to cite this book chapter:

Moreland, J. and Hadley, D. (with A. Tuck and M. Rajic). 2020. Sheffield Castle: archaeology, archives, regeneration, 1927-2018, pp. 29-67. York: White Rose University Press. DOI: https://doi.org/10.22599 /SheffieldCastle.b. CC BY-NC 4.0, https://creativecommons.org/licenses/by-nc/4.0 
in 1927, and as local secretary of the Society of Antiquaries Armstrong $(1930,9)$ was appointed to record this work and 'on its behalf also' by the Committee of the Hunter Archaeological Society. In a lecture to the Sheffield Trades Technical Society in 1935 Joseph Himsworth embellished this account, imbuing it with a sense of mystery and urgency. Thus, he reported that, although most 'expert opinion' favoured the land in 'the angle formed by the Junction of the Sheaf and the Don', 'considerable controversy' remained locally regarding the site of Sheffield Castle (reflecting the claim by Armstrong (1929b) in the handwritten draft of his partially completed book on the castle that, until his work, 'the actual position of the [castle] building remained a matter of conjecture'). Himsworth told the audience of a later lecture, on '500 Years of Sheffield Trade and Sheffield Castle', that when 'the city authorities cleared the area between Exchange Street, Waingate and the Don of what were chiefly $17^{\text {th }}$ and $18^{\text {th }}$ century buildings' (see Figure 1.10), and it became clear that the Brightside and Carbrook Co-op was going to build on part of that land, 'local antiquaries bestirred themselves'. Armstrong was appointed to 'watch' the excavations, in turn inviting Himsworth to assist (Himsworth 1937, 4-5; 1935, 5). In these compressed narratives, historians and archaeologists respond to an emerging threat/opportunity, and Armstrong and Himsworth end up recording the uncovering of Sheffield Castle. In fact, the process was more protracted, and the 'position' of the castle less mysterious, than all this implies.

The location of the castle was not a controversy for the Reverend Edward Goodwin, who wrote in 1764 that 'at the NE part of the town, where the two rivers meet, formerly stood a strong castle, which was demolished in the civil wars', but lived on in the names of 'the streets and places thereabouts ... Castle-hill, Castle-Fold, CastleGreen, Castle-Lathe etc.' (Goodwin 1764, 157). Nor was it a mystery to Thomas Winder (1910, 55), who told the British Association for the Advancement of Science in 1910 that 'Sheffield Castle was situate at the confluence of the rivers Don and Sheaf'. Not long afterwards 'archaeological traces' of the castle came to light (see Chapter 1, Section: The castle 'made untenable' for evidence that parts of the castle remained visible into the early 20th century; also Chapter 7, Section: Steel City). In a letter to the editor of the Sheffield Daily Telegraph, published on $1^{\text {st }}$ July 1914, 'W' (probably architect, local historian, and FRSA James Ragg Wigfull (Ball 2012)) reported that while walking along Exchange Street he had observed what he took to be official surveyors ... at work' on the site, following the 'demolition of the old buildings and the clearing of the ground. He hoped that these men were 'marking on their plans and making notes of anything ... which might eventually help to explain the lay of the Castle and its moat' ('Sheffield castle', 1914). A short note by Wigfull (1916, 239; also 'Sheffield's Streets', 1922) in the Transactions of the Hunter Archaeological Society reported on the ensuing discovery of 'some slight traces of the Castle of Sheffield', comprising 'fragments of a paved roadway' close to the Royal Hotel on Waingate, and 'the outline of a ditch' which seemed to run parallel with Exchange Street.

The construction of the Co-op's city-centre store, and other proposed developments in the area, were delayed by World War I, but, even before the first steps towards redevelopment were taken in that post-War period, there were calls for 'action' on the castle site - and from Joseph Himsworth, no less. On $1^{\text {st }}$ July 1924, he wrote to the editor of the Sheffield Daily Telegraph praising the results of recent excavations on the site of Beauchief Abbey, a 12th-century monastic foundation in what is now south-west Sheffield, and expressing the hope that 'Sheffield castle [will be] next. He argued that the position of the castle is well known 'within a few yards', that 'a few trial holes would cost very little for labour', and noted that 'offers of help for the purpose' had been made - all that was lacking was, he thought, 'the man to organise the effort' (Himsworth 1924, 6). That man was soon to appear - but he did so at the end of a long period of calls for action to understand and preserve the remains of Sheffield Castle, and an intermittent process of regeneration in the area, not as a result of the burst of activity in 1927 implied by Armstrong's paper.

The excavations overseen by Armstrong and Himsworth would finally settle whatever 'controversy' remained about the location of the castle. ${ }^{2}$ However, given the conditions under which they were conducted, and the character and intellectual background of those involved, much uncertainty remains - about, for example, the castle's origins, development, daily life and the manner and timescale of its demise - and Armstrong's publications offered problematic interpretations in this respect. To achieve the fullest understanding of what they saw we need to interrogate a much wider array of evidence than the 1930 paper. Our archival research provides fresh insights into the two men who oversaw the 'rediscovery' of Sheffield Castle in the course of the

\footnotetext{
2 That there was some controversy can be seen in the fact that an early newspaper report on the question of what to do with the remains is prefaced by the remark that 'It is a strange thing that the site of such a place as this, certainly the most important and imposing building in medieval Sheffield, should have passed out of record' (Sheffield Daily Telegraph, $13^{\text {th }}$ October 1927, under Current Topics).
} 
early 20th-century regeneration of the area, and we begin our discussion with an analysis of their interests, experiences and motivations.

\section{Albert Leslie Armstrong: more than just the 'gifted amateur'}

Albert Leslie Armstrong (known as Leslie) began his working life with a firm of architects and surveyors in his hometown of Harrogate (Yorks), and in 1912 moved to Sheffield to work for the Inland Revenue. During World War I he served as a lieutenant with the Royal Engineers (Burkitt 1963, xi). From an early age, however, archaeology was his 'guiding passion' (Allsworth-Jones 2014, 8), and, mentored by famed geologist and archaeologist Professor William Boyd Dawkins, he acquired considerable experience working on, and directing, archaeological projects, particularly at prehistoric sites including the Neolithic flint mines at Grimes Graves (Norf) between 1916 and 1939 (e.g. Armstrong 1924; also Russell 2000, 25, 37; Varndell 1991), the caves at Creswell Crags (Derbs) from the 1920s (Armstrong 1926a; 1929d; 1932;1956) and Palaeolithic and Mesolithic 'open sites' in Lincolnshire (e.g. Armstrong 1923). Armstrong was not a 'professional' archaeologist - they were still very rare in the 1920s and 1930s (Barker 2007, 383) - but he was undoubtedly a very experienced one. Although his work has not been without controversy - for example, the questionable 'authenticity' of some of the engraved and carved figures he found at Creswell and Grime's Graves (Burkitt 1963, xi-xii; Bahn and Pettitt 2009, 14; Hutton 1997) 3 - it is generally accepted that Armstrong was a 'highly capable and talented archaeologist' (Russell 2000, 41), whose 'records of his excavations in Pin Hole [cave] are far better than any others that exist for Creswell' (Bahn and Pettitt 2009, 14; also Burkitt 1963, xi-xiv; Allsworth-Jones 2012, 30).

Armstrong was one of the most respected practitioners in his field, advising and debating with some of the best-known prehistorians of the time - including Abbé Breuil (France), Raymond Dart (South Africa) and Louis Leakey (East Africa). He died ( $3^{\text {rd }}$ December 1958) at Johannesburg railway station while 'making his final visit to Professor Dart' (Kitching 1963, 2; Dart 1973, 424), while Leakey thanked 'my friend ... Mr Leslie Armstrong' for discussions that informed his The Stone Age Cultures of Kenya Colony (1931, xiii). Some of his interactions were not entirely 'harmonious', however. Brian Fagan (2001, 44-5) describes a meeting of the Prehistoric Society of East Anglia in 1932, where the 'venerable but troublesome' Armstrong lambasted a young Grahame Clark as 'you impudent puppy' after the latter had 'brashly' corrected his identification of a prehistoric flint. This marked the beginning of a brief feud with Clark (and Stuart Piggott) played out in the pages of the Proceedings of the Prehistoric Society (Russell 2000, 24-5).

By the time he oversaw the excavations at Sheffield Castle, Armstrong was one of the most influential archaeologists in the country - Roger Mercer $(2010,50)$ refers to him as one of those who 'controlled the levers of the profession'. In the 1920s the British Association for the Advancement of Science, in collaboration with the Royal Anthropological Institute, established a research Committee for the Exploration of Derbyshire Caves, appointing Armstrong as field archaeologist (Allsworth-Jones 2014, 10; White et al. 2009, 227). His early work at Grime's Graves was funded by the Percy Sladen Memorial Fund (administered by the Linnean Society) (Armstrong 1924, 182), and in 1938 he won a research grant from the Lord Leverhulme Fund to carry out research on the prehistoric archaeology of the Trent gravels (Armstrong 1942, 34). He published in what are still the leading journals in the field - including Man (e.g. 1925; 1936) and the Proceedings of the Prehistoric Society (e.g. 1924). As well as publishing numerous excavation reports, he used his knowledge, expertise and wide-ranging contacts to write broad overviews, comparing, for example, the Mesolithic cultures of East Yorkshire and Denmark, or the Mousterian industries in South Africa and Europe (e.g. Armstrong 1924; 1936; Dart 1973, 424). This is a long way from Sheffield's medieval castle, but to assess his work there it is essential to understand the experience and stature of a man for whom the phrase 'gifted amateur' (Burkitt 1963, xiii) does scarce justice. He was well connected, and, as well as being local secretary of the Society of Antiquaries, was President of the Sorby Natural History Society (1927), a founder member (in 1935) of the British Speleological

\footnotetext{
${ }^{3}$ Miles Russell $(2000,41,45)$ went so far as to accuse Armstrong of faking the 'flint crust engravings' from Grime's Graves, even suggesting that he may have been 'implicated in the manufacture' of the sculpture that became known as the Grime's Graves Goddess. His evidence is, however, hardly convincing, with the Grime's Graves engravings bearing little resemblance to the French examples on which they were supposedly based (see Russell 2000, figs 17 and 18). He cites the testimony of Ethel Rudkin (to Kevin Leahy), who was at Grime's Graves when the 'Goddess' was discovered, to cast doubt on Armstrong's behaviour, but neglects to tell us that 'in her conversation with Leahy [Mrs Rudkin] was adamant that Armstrong's figurine was genuine' (Varndell 1991, 104; 2005).
} 
Association (Craven 2001, 100) and a very active member of both the British Association for the Advancement of Science and the Hunter Archaeological Society, and was Vice President of the latter for 27 years (AllsworthJones 2012, 30; Burkitt 1963, xiii).

Despite his considerable experience, Armstrong's work on Sheffield Castle was, nonetheless, a rare foray into the archaeological record of historical periods (Figure 2.1). ${ }^{4}$ In his lecture to the Hunter Archaeological Society on $11^{\text {th }}$ December 1928, he expressed some unease about that:

I appear before you tonight as a creature of circumstances. Mediaeval history is not really my forte. It is not 'my period'. I am more at home delving into the pre-history of mankind \& piecing together from scraps of bone \& tools of flint something of man's early story. In comparison with that, mediaeval history is an exact science (Armstrong 1928a).

Despite his international standing, he goes on to say that, in the presence of such 'well-known writers on local history' as Canon Odom, Charles Drury, Walter Hall, Wigfull and Himsworth, perhaps 'I am the wrong man to be on the platform tonight'. However, he admitted that he was 'not unwilling to watch the excavations made on the site of our ancient castle', stressing the value of his previous extensive experience in dealing with 'much more intricate \& difficult [archaeological] problems elsewhere' (Armstrong 1928a). The content of his lecture, and the quality of his later publication, make it clear that, despite his misgivings (are there hints of feigned modesty here?), he was the right man for the job (Figure 2.2).

However, we need to be clear that, unlike at Creswell or Grime's Graves, at Sheffield Castle Armstrong did not direct a programme of archaeological excavations; rather, he conducted what we would today call a 'watching brief'. This was a practice adopted at Aberystwyth Castle (Dyfed) by Harold Hughes (1904, 317-18), who, despite instigating the excavations, inspected work undertaken by the Borough Surveyor. Armstrong felt it was his 'bounden duty ... to describe ... as well and as lucidly as I am able, what has been found \& how far the discoveries made have advanced our knowledge of Sheffield's ancient Castle' (Armstrong 1928a) and to 'watch this work ... to secure a record of the various findings [and] to obtain every possible shred of evidence which was revealed' (Armstrong 1930, 9, emphasis added). He soon realised that deep deposits (between 4 and $11 \mathrm{~m}$ ) had accumulated over the remains of the castle (Armstrong 1930,14-15), and his archaeological efforts mainly consisted of inspecting the foundation shafts set out in a grid over the site and other holes dug through these deposits (Figure 2.3). This resulted in only partial glimpses of the castle, which, nonetheless, confirmed its imposing scale - "bastion" ${ }^{5}$ towers $(12.2 \mathrm{~m}$ in diameter) flanked the entrance on its south-eastern side, and the castle was surrounded by a deep moat, passage over which was facilitated by a drawbridge. While it is easy to lament this chequerboard view as one of the limitations consequent upon doing archaeology side-by-side with commercial development, when considered in the context of 1920s archaeology, and of Armstrong's work elsewhere, we can see that it was not, in the end, so different from normal contemporary practice (see Larkin 1927 for similar undertakings on the site of Liverpool Castle).

Contrary to received wisdom within the discipline - which imagines it to be an advance of the late 1950s and 1960s (Collis 2001, 11-16; Lucas 2001, 52) - open-area excavation was archaeological 'best practice' in the 1920s; as, in fact, it had been for Flinders Petrie $(1904,41-2)$ at the very beginning of the 20th century. The question was the means by which such excavation should be achieved. As both John Collis (2001, 3-16) and Gavin Lucas (2001, 36-47) have pointed out, these apparently simple methodological concerns were ultimately dictated by wider theoretical views on the forces driving the historical process. From the early 20th century,

${ }^{4}$ Although he had recorded Roman and medieval material in some of his cave excavations (e.g. Armstrong 1923, 413).

5 While the term 'bastion' was in common parlance in the early 20th century to describe circular towers projecting from a castle wall (e.g. Hughes 1904, 318; Barber 1931, 207), this use is inaccurate, as a bastion - an angular projection from a wall enabling projectiles to be fired along its face - is more usually associated with post-medieval fortifications rather than medieval castles. In Chapter 5 we will return to consider whether the towers were D-shaped rather than circular (as Armstrong supposed).

Figure 2.1 (page 32): Leslie Armstrong inspecting remains of Sheffield Castle in 1927. In his diary entry for $5^{\text {th }}$ December, Joseph Himsworth records that he had met Armstrong on site 'to view more masonry which is evidently a portion of a bastion ... Photographed it three courses high', and it is this visit that is captured in this photograph. Courtesy of Museums Sheffield. 


\section{CITY OF}

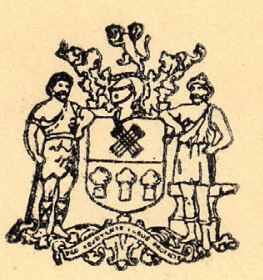

\section{SHEFFIELD.}

\section{MAPPIN ART GALLERY。}

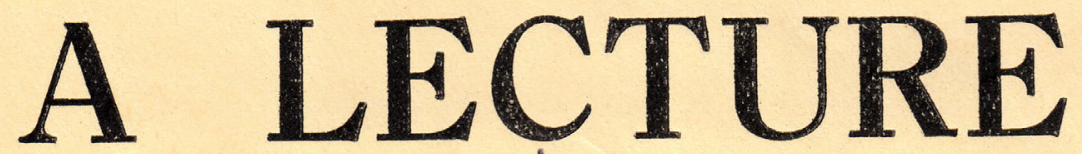

WILL BE DELIVERED IN THE

MAPPIN ART GALLERY, WESTON PARK,

ON

Thursday, March 7th, 1929, at 7-45 p.m.

BY

A. LESLIE ARMSTRONG, F.S.A.,

ON

\section{"The Story of Sheffield Castle."}

(RELICS from the site of Sheffield Castle are on

Exhibition in the Gallery.)

The Lecture will be delivered in the CENTRAL HALL, and will be Illustrated by LANTERN SLIDES.

\section{Chairman - - Councillor A. BARTON}

(Chairman of the Mappin Art Gallery and the Libraries and Museums Committees).

\section{ADMISSION FREE.}




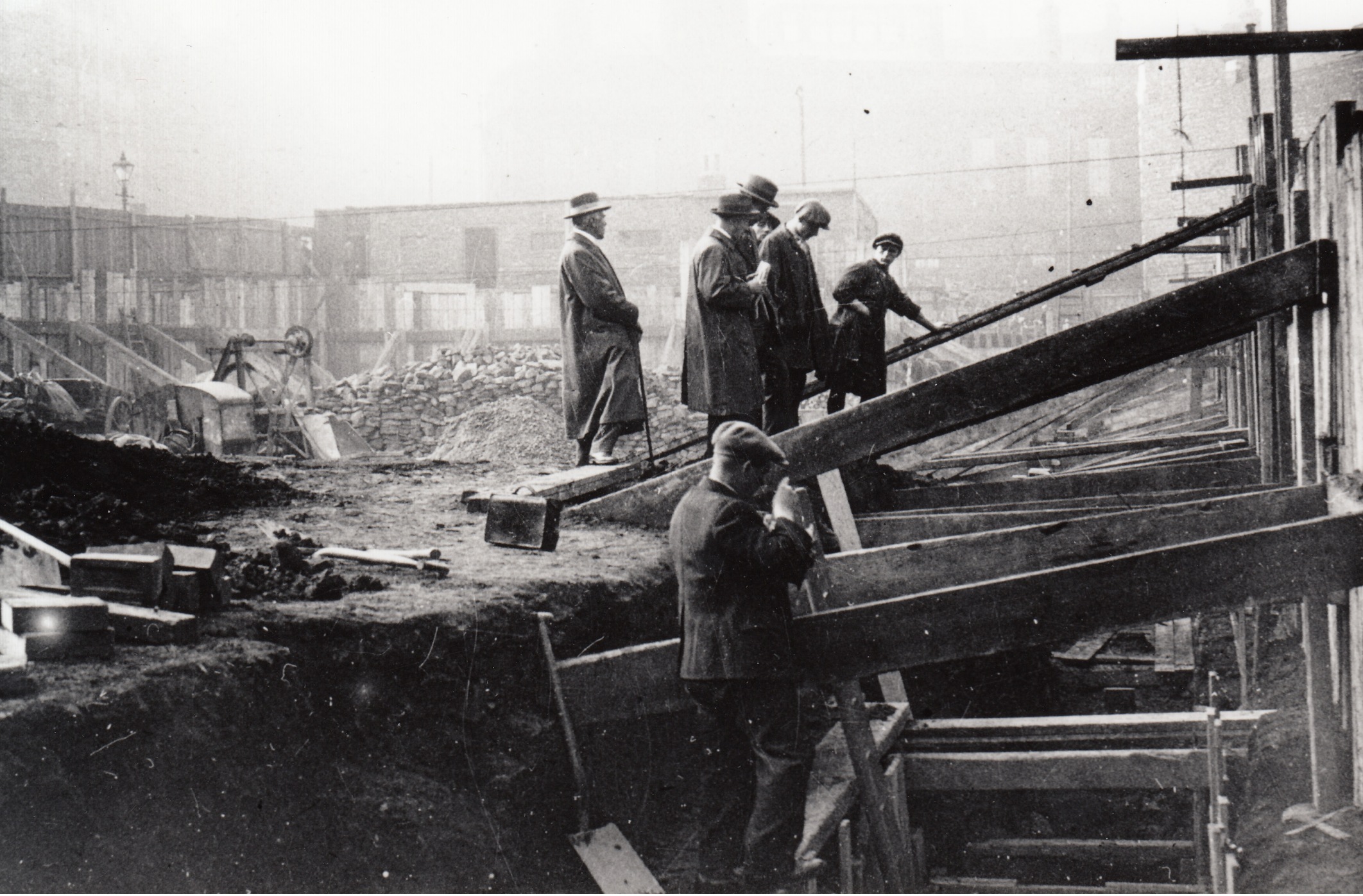

Figure 2.3: A photograph taken by Joseph Himsworth when he visited the building work on Castle Hill in October 1927. He was accompanied by Leslie Armstrong and J. R. Wigfull. A similar photograph also taken at this time is included in Himsworth's diary. Armstrong is second from the left in the group in the middle of the picture. Courtesy of Museums Sheffield.

archaeologists moved from describing the societies whose remains they encountered to trying to understand the 'dynamics' which led to change over time in, for example, burial traditions, settlement form and ceramic styles. Throughout much of Armstrong's archaeological career, explanations for change were framed within the culture-historical paradigm, in which such groupings of objects and traditions were seen as manifestations of 'culture-groups', themselves identified with the ancient 'peoples' named in the historical sources (Trigger 2006, 244-8). In an explanation that owed more to the emerging racial perspectives on past and present then coming to the fore in Europe than to anything that actually happened in the past, the catalyst for change, in culture groups/peoples, was located in 'external influence, usually in the form of invasions' (Collis 2001, 9; Trigger 2006, 237-8). This was also a framework in which archaeological explanation depended heavily on texts (Moreland 2010, 163).

Figure 2.2 (page 34): Handbill advertising a talk about Sheffield Castle. Given by Leslie Armstrong at the Mappin Art Gallery, Sheffield, on $7^{\text {th }}$ March 1929. Courtesy of Museums Sheffield. 


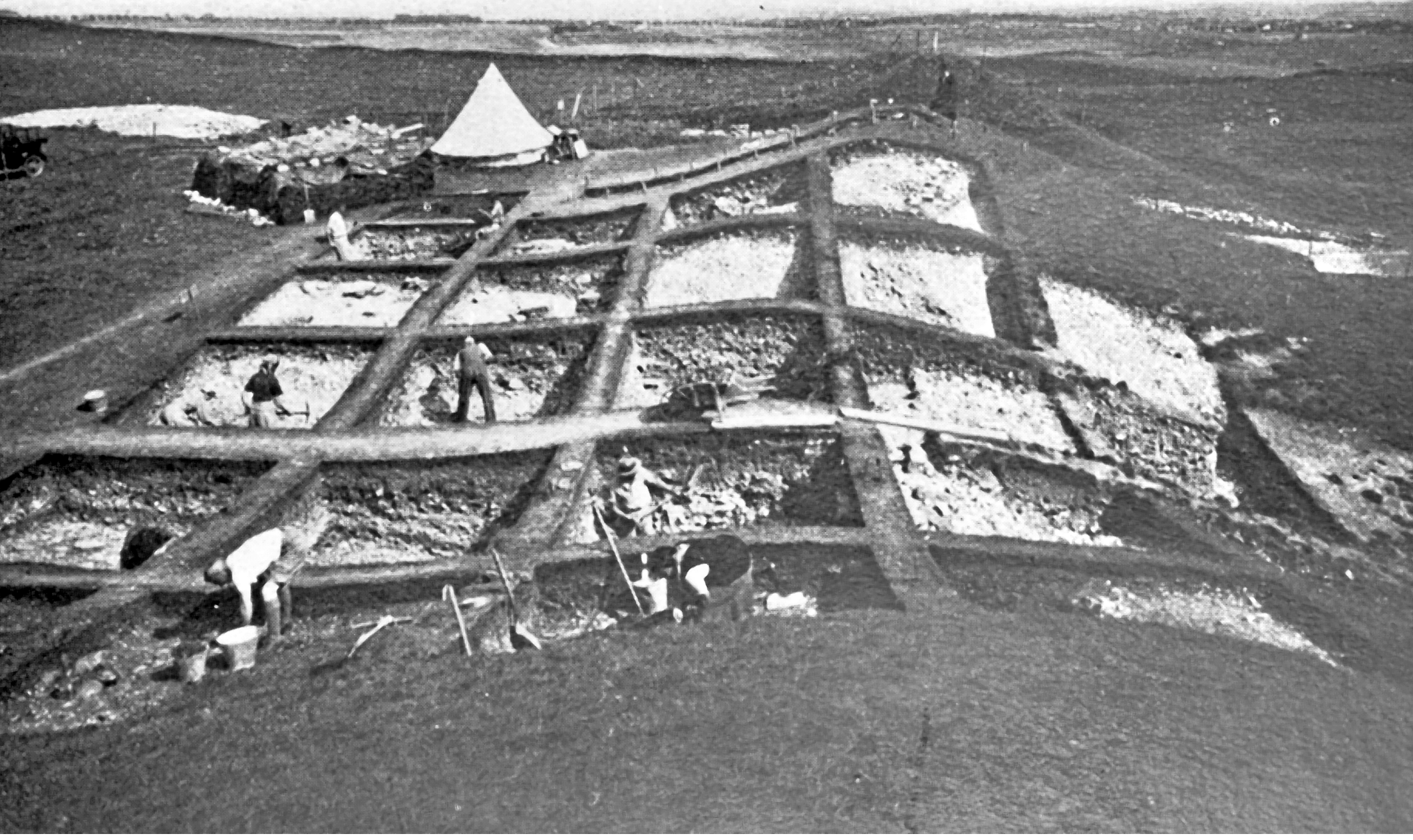

Figure 2.4: Mortimer Wheeler's excavations at the eastern entrance of Maiden Castle (Dorset). Here he was using the box grid system. By kind permission of the Society of Antiquaries of London.

The key point here, as John Collis $(2001,9)$ observes, is that within this explanatory framework 'the emphasis was on short-term changes, with [therefore] a need for precise dating. The result, as Wheeler (1927) set out, was a new focus on stratigraphy and on 'sections' in which the sequence of such changes was manifest with, in some (extreme) cases, layers being treated as if they 'stood for' peoples, and 'major discontinuities' in the section being 'read as major changes in culture groups' (Lucas 2001, 47; Lyman et al. 1997, 77). This was a theoretical perspective favouring excavation strategies which generated sections, exemplified in Mortimer Wheeler's 'box system' - 'a series of squares, a grid, dug so that a balk is left between each pair of adjacent squares' (Wheeler 1954, 64; Lucas 2001, 39; Figure 2.4).

The grid pattern of foundation shafts that formed the basis for Armstrong and Himsworth to view the archaeology of the castle site did not, therefore, differ in essence from that which would have resulted from the use of the ideal methods proposed in archaeological manuals from the 1920s onwards - although the 'baulks' were much wider than the ' 3 foot standard' proposed by Wheeler (1954, 65; Atkinson 1946, 50). We also know that Armstrong $(1931,245-6)$ himself deployed a version of the grid system during his excavations at Bambata Cave in Rhodesia (modern Zimbabwe) in June $1929 .{ }^{6}$ Driven by the demands of commercial construction, the process of excavating the grid of foundation shafts on the castle site certainly differed from that advocated by, for example, Kathleen Kenyon in her Beginning in Archaeology (1952, 77-80), but was perhaps similar to some of Armstrong's excavations at Grime's Graves, where, 'by the splendid energy of the workmen', a shaft $12 \mathrm{ft} 6 \mathrm{in}(1.98 \mathrm{~m})$ deep and measuring $10 \mathrm{ft}(3.05 \mathrm{~m})$ by $9 \mathrm{ft}(2.74 \mathrm{~m})$ at the rim, was 'bottomed' in two

${ }^{6}$ Although here the concern seems to have been 'to ensure an accurate record of the position of important finds', and only one baulk was maintained through the middle of the excavation (see Armstrong 1931, fig. 3). 
days (Armstrong 1924, 119). He also excavated there a gridded system of 52 'trial holes' to obtain insights into the location and extent of buried 'primitive flint workings' and high-quality floorstone flint (Armstrong 1924, 191, fig. 4).

The focus on stratigraphy, manifest in 'Wheeler's pioneering work in the 1920s' (Lucas 2001, 52; also Piggott 1965), led to calls to refrain from digging in arbitrary depth lines, or spits (Wheeler 1954, 53-4) - but Armstrong seems to have persisted with 'traditional' methods. He certainly differentiated layers stratigraphically (by content, composition, texture etc.), and he did this both as the excavation was taking place and later by consulting the sections (e.g. 1924, 184; 1931, 244; 1956, 95) - but he also excavated in arbitrary spits. At Bambata Cave, for example, he dug in 'layers' of ' 6 inches ... for the top 18 inches and below that level layers of 12 inches were taken out' (Armstrong 1931, 244). Section drawings form an important interpretative element in his published work (from Creswell, Grime's Graves and Bambata), and, in keeping with the pervading cultural-historical perspective, he very often added 'cultural' labels to layer descriptions (e.g. Armstrong 1931, fig. 4; 1942, fig. 6). However, he did not blindly accept cultural-historical explanations for change - arguing, for example, that 'Clactonian' and 'Levalloisian' stone tools are more likely to represent technological adaptations to climate change rather than 'two different races of men, the one ... occupying a particular region when the rigours of climate had compelled the other ... to migrate' (Armstrong 1942, 42-3; Figure 2.5). On the other hand, it is important to recognise that, in the tradition of General Pitt-Rivers 40 years earlier, Armstrong frequently published 'typical' sections comprising schematic, but measured, representations of the sequences on an excavation (see, for example, Armstrong 1923, fig. 2; 1925, fig. 4; 1931, section 7; 1956, fig. 27; Lucas 2001, 23). This helps to explain an issue which Leslie Butcher later had with Armstrong's presentation of his findings

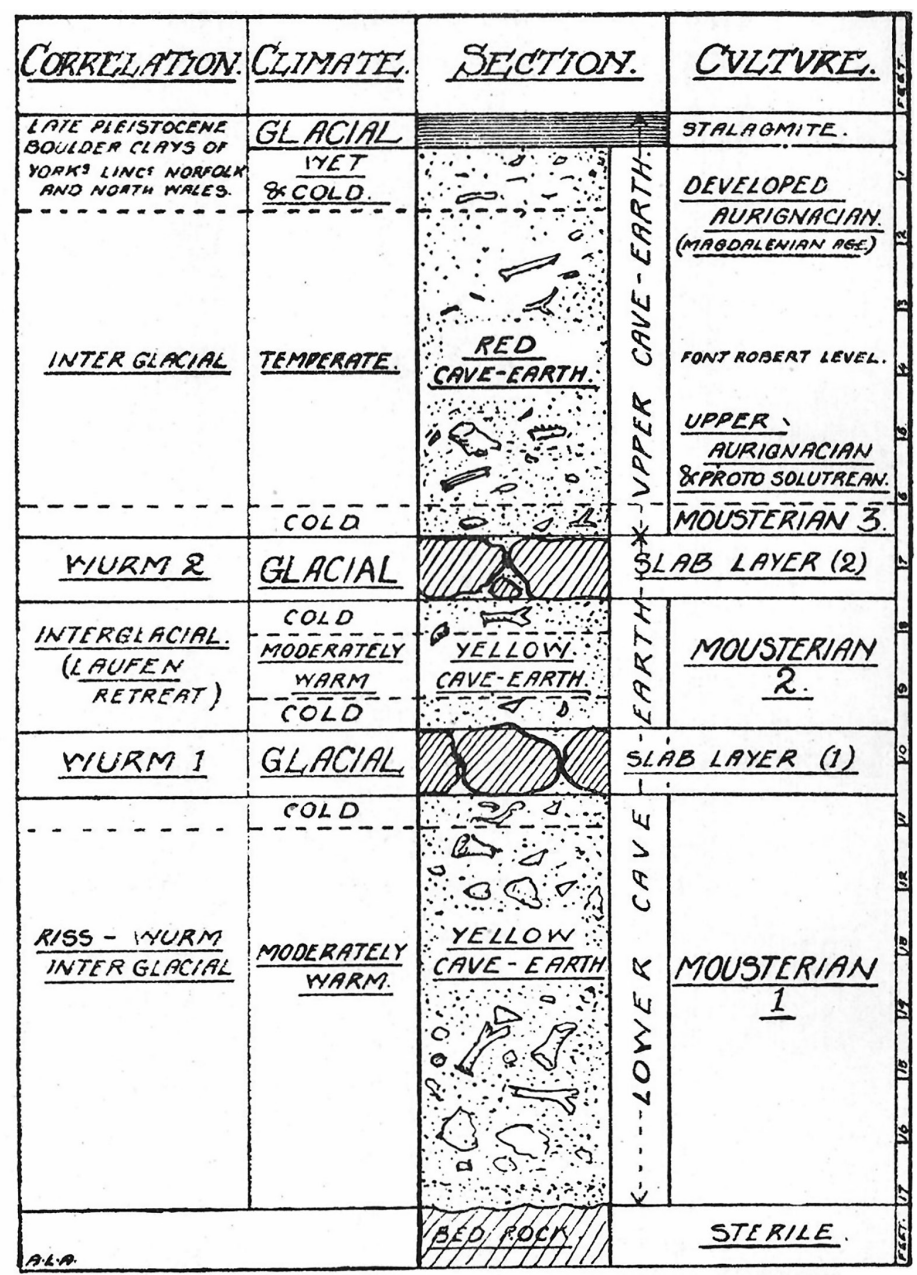

Typical section of the Pin Hole Cave, Creswell.
Figure 2.5: 'Typical' section drawing from Leslie Armstrong's excavations at Pinhole Cave, Creswell (Notts). Note the correlation between stratigraphy, culture type and 'the rigours of climate' (Armstrong 1942 , 42). Image reproduced by permission of the Derbyshire Archaeological Society. 
(Chapter 5, Section: The moat), and, along with the observation on his digging technique, it might well confirm Brian Fagan's $(2001,44)$ description of him as 'old school'.

The biggest difference between emerging archaeological best practice and the situation Armstrong and Himsworth encountered on the castle site in late 1927 is that the box grids of the former were only ever intended to be temporary. The ideal was open-area excavation; the box grid was seen as the best way to achieve this while the stratigraphy in the sections helped to retain tight chronological control (Kenyon 1952, 94; Wheeler 1954, 64; Lucas 2001, 39). Once that had been secured, Wheeler $(1954,65)$ proposed, 'the barriers between the squares can be removed without loss of vertical evidence and the whole plan laid bare' (see also Atkinson 1946, 50-1). This, of course, was never possible at Sheffield Castle, where the foundation shafts were to provide the permanent supports for the new buildings on the site (see Figure 1.14). While Armstrong did not always use the most 'up-to-date' methods, his archaeological expertise, and especially his ability to read stratigraphy as it appeared in deep sections (whether in the baulks of cave excavations, the shafts of flint mines, or the gravel workings at Hilton and Willington in the Trent Valley; White et al. 2009, 228), would have been invaluable assets as he sought to make sense of the archaeology being exposed in the course of redevelopment.

\section{Joseph Beeston Himsworth: cutler and artist}

As we noted in Chapter 1, the records that survive of Armstrong's work on the castle site, while vital, are limited. We are fortunate, therefore, to have a second archive, that of Joseph Himsworth, who worked with Armstrong $(1930,27)$ both in recording the excavation and producing his paper (Figure 2.6). This comprises his diary account of the uncovering of the castle, fragments of his personal site diary, correspondence, numerous photographs, and the texts of three lectures which drew upon the results of the excavations.

Himsworth (1953, vii) was a cutler and silversmith by trade, and proud to continue 'the family tradition of more than 220 years of active participation in the cutlery trade in the city of Sheffield'. His training in design and the use of fine materials at the Sheffield School of Art informed his craft and he was a keen artist, exhibiting his paintings in local art clubs ('Sheffield Art Society and Sketching Club', 1896). He was a member of the Sheffield Artcrafts Guild, founded by his friend and sculptor Charles Green in 1894, becoming Deputy Master (1926-28, 1930-31) and Master (1932-34; Conroy 2008, 47; Himsworth 1953, viii). In common with many in Sheffield at the time, Himsworth was inclined to the socialist ideas of William Morris, John Ruskin, Edward Carpenter 'and the early Bolsheviks' (Wagner 2012, 26; n.d., 4; Rose 2001, 190-2). Indeed, in 1934, with his wife Dora and daughter Joyce, he visited Moscow and Leningrad (Soviet Union), regarding it as 'the highlight on my experience in the whole of my life' (Himsworth 1936). Joseph Himsworth's (1964) characterisation of the Guild tells us much about himself and his worldview:

Over a long period all the chief designers in the Sheffield stove-grate firms, as well as in the silver and plate trade, were members. There were also a number of independent freelance men who testified to that independent spirit always so marked among those who disliked the restraint of factory life ... There was, at times, a Bohemian element in strong measure among the members, but it was largely kept in control by industrial demands with which they were in daily contact (cited in Conroy 2008, 48).

He was a Fellow of both the Royal Society for the Encouragement of Arts, Manufactures and Commerce and the Council for the Preservation of Rural England, President of the Trades Technical Preservation of Old Tools Society (1939-45) and a Freeman of the Company of Cutlers in Hallamshire (Himsworth 1953, viii; Wagner n.d., 4-5). Joyce went on to become an internationally renowned silversmith, and c.1940 she designed and made a bracelet for her father with links epitomising some of the central concerns of his life - a stylised landscape, a cutler's grinding wheel ... and a spade and pick, almost certainly symbolising his passion for archaeology'

Figure 2.6 (page 39): Photograph of Joseph Himsworth as a young man. Unknown date but probably taken between 1910 and 1920. Courtesy of Museums Sheffield. 


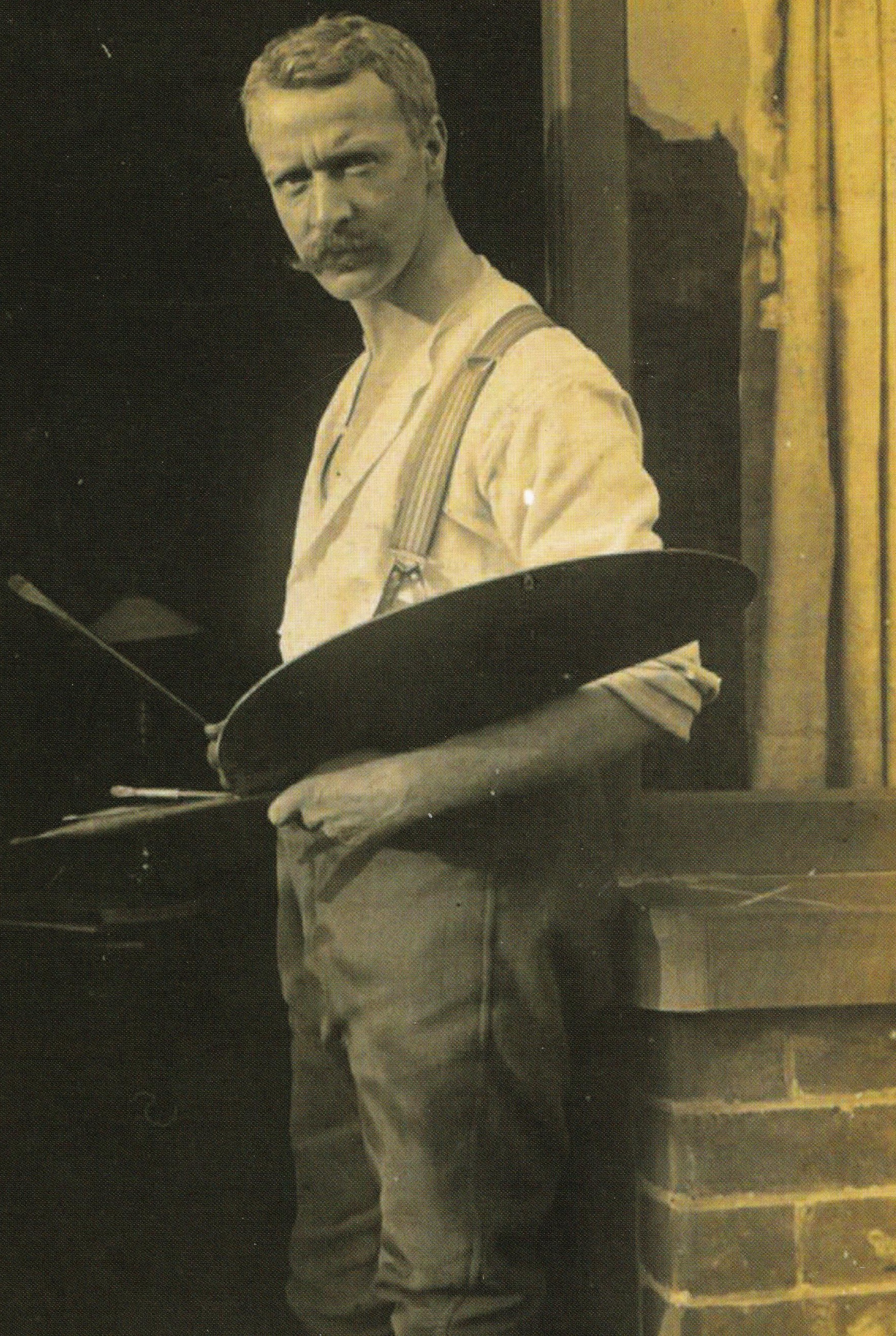


(Conroy 2008, 52). Himsworth's diary bookplate similarly contains a crossed spade and pick and a grinding wheel (Himsworth 1927-42; Figure 2.7).

There is no doubting Himsworth's passion for the archaeology and history of Sheffield. In his lecture to the Hunter Archaeological Society in December 1928, Armstrong described him as 'storing up facts and figures about Sheffield's past ... for years' - perhaps in the series of notebooks Himsworth (1944, 3-4) referred to in a lecture entitled 'Eye witnesses of Sheffield Castle'. Some of his interest may, in fact, have been stirred by Armstrong - he speaks of how the latter 'fanned the flame of interest in pre-history through the years', and he was clearly indebted to him (not least for some of the illustrations) for the opening sections of his famous The Story of Cutlery (1953, xii, 17-29). He seems to have been especially interested in Sheffield Castle. In a lecture to a section of the Sheffield Trades Technical Society in 1935 - entitled 'Some Old Sheffield Stories, Discoveries \& Art' - he recalled that as 'a youngster I used to like to think that a namesake of mine who was in Sheffield Castle when it surrended [surrendered] [to Parliamentarian forces, during the English Civil War] in August 1644, was a direct ancestor of mine' (Himsworth 1935, 1; also 1944, 2, and below, Section: Himsworth's historical perspective). Himsworth belonged to the Prehistoric Society (his aforementioned bookplate contains images of a stone axe and a barbed and tanged arrowhead) and was an active member of the Hunter Archaeological Society (President from 1958 to 1968) (Himsworth 1953, viii; Wagner 2012, 26).

The original version of Himsworth's diary (1927-30) is a handwritten account entitled 'THE UNCOVERING OF SHEFFIELD CASTLE SITE. It was discovered by Sheffield resident, and (like Himsworth) former President of the Hunter Archaeological Society, Pat Wagner (pers. comm.) in a second-hand book shop in Sheffield about 30 years ago, in another of the many acts of serendipity that has characterised the archaeological recording of Sheffield Castle. It comprises two physically distinct parts (Figure 2.8). Himsworth started it

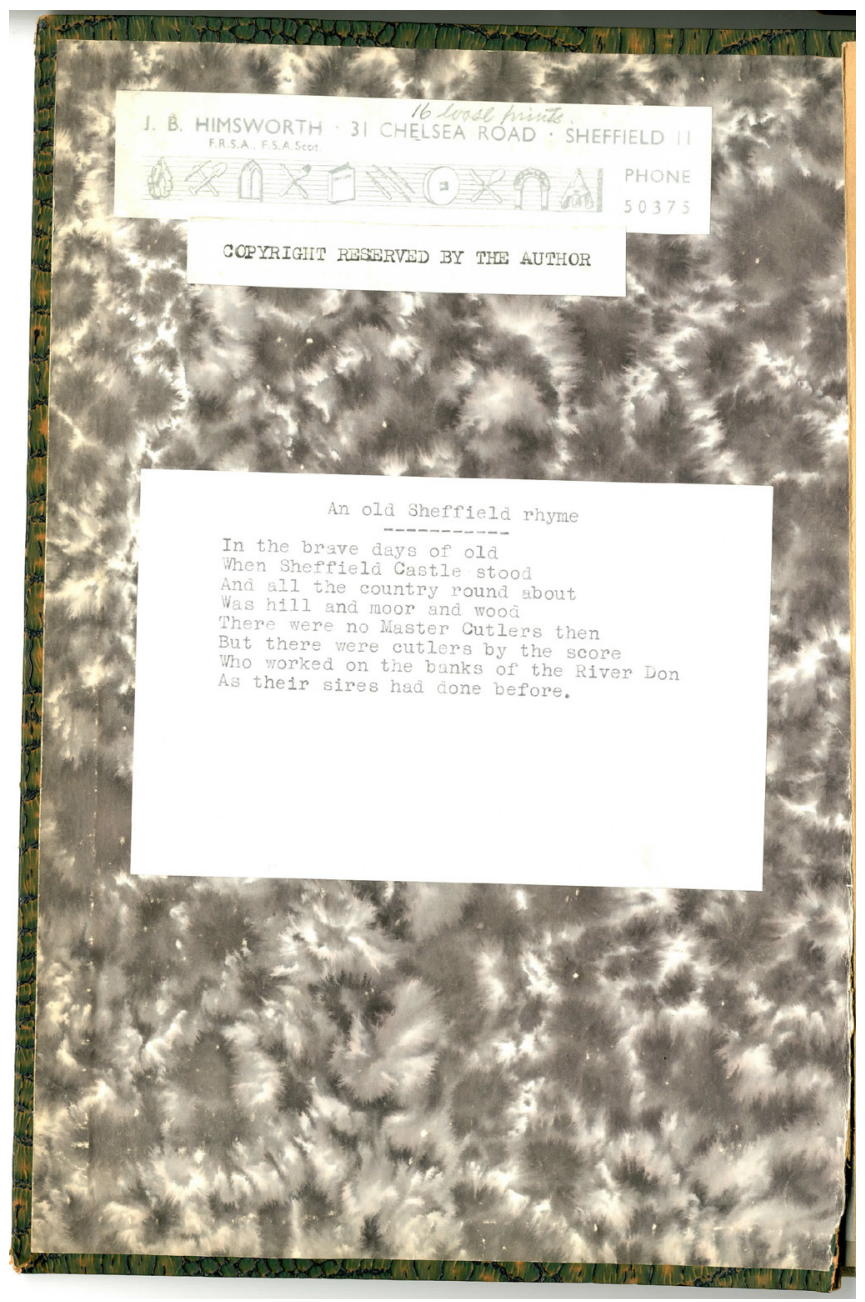

Figure 2.7: The inside cover of the diary of Joseph Himsworth typed by Harry Lea. The bookplate shows his interests in archaeology, Sheffield crafts, and ancient monuments, and beneath is 'An old Sheffield rhyme. Courtesy of Museums Sheffield. 
THE. UNCUVERIIVG. OF. SHEFFIELD. CASTLE. SITE.

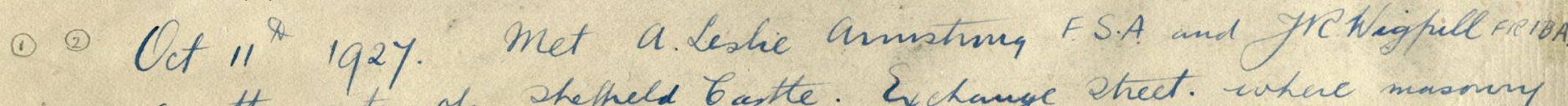
ow the site of sheffeld bastle. Exchange strect. where masony

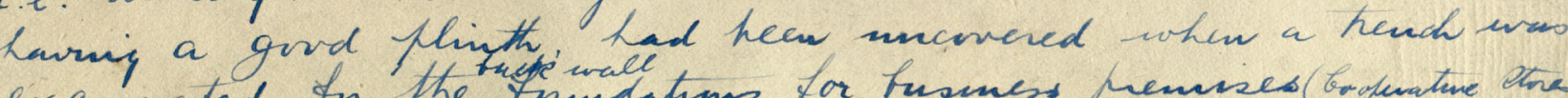

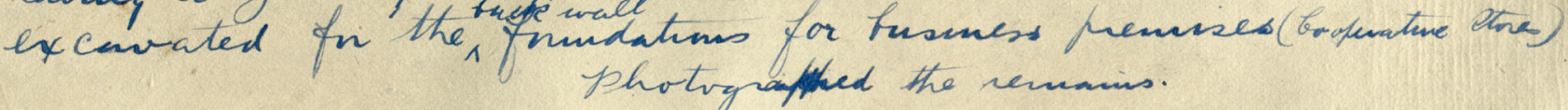

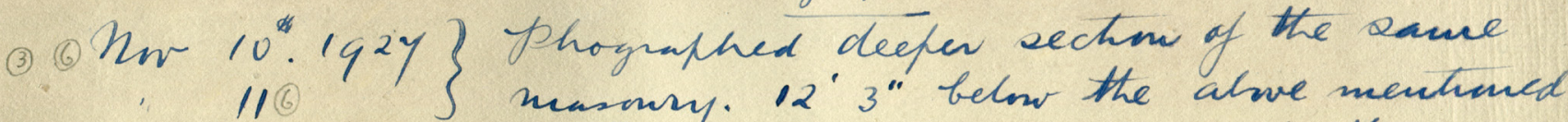
phinth. At the fosint undonbted evidence of the sovat

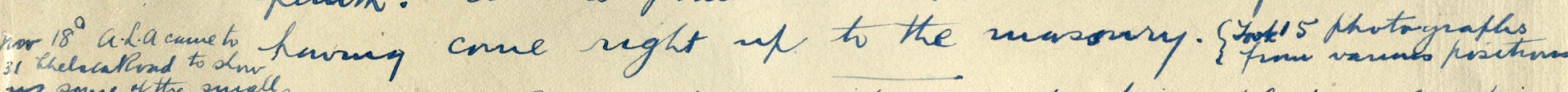

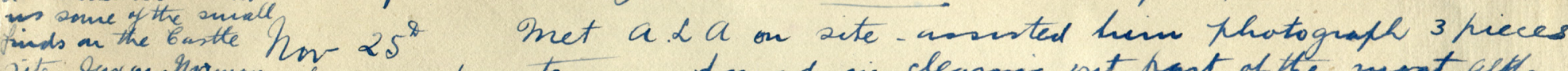

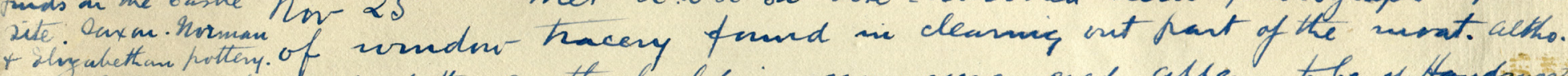

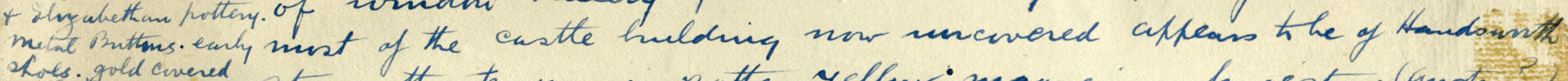

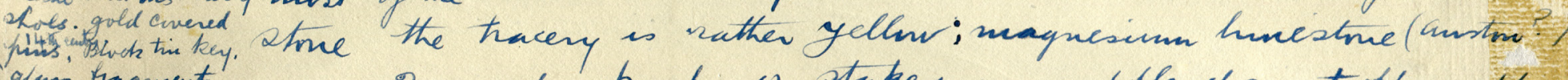

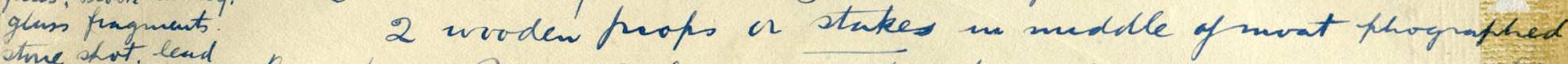
mind muskt dee 5/27. Qaw A.K.A an sute to reeir aw hatal medals is evidently a fortaon of a bastum. Thes is miside the area of the Bluch vak connter new hilding. Photograthed it. 3 curses high uniluw to a dimino Hec 6/27. Photos taken of mose crasses

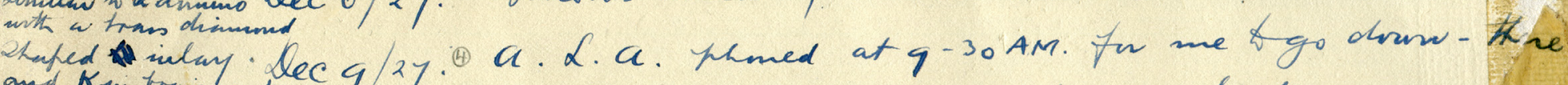

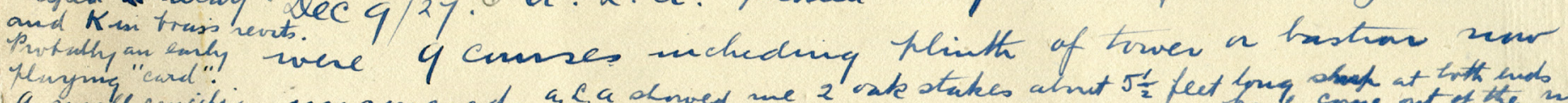

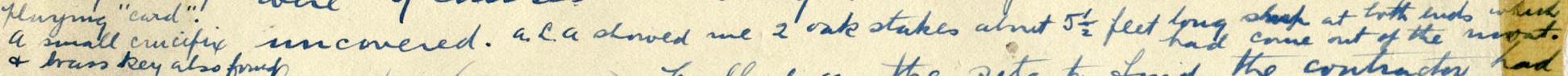

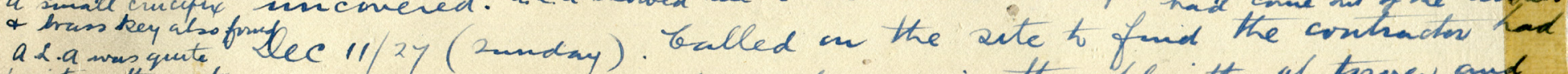

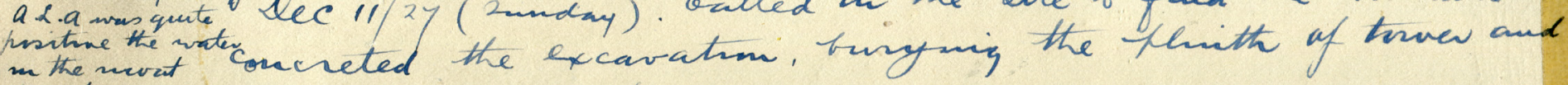
hadken several cosses of masomsy.

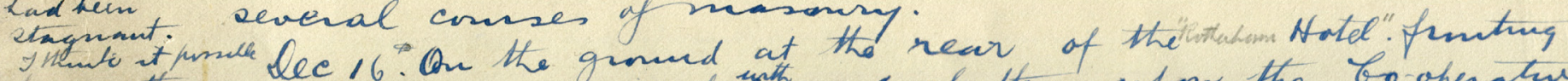

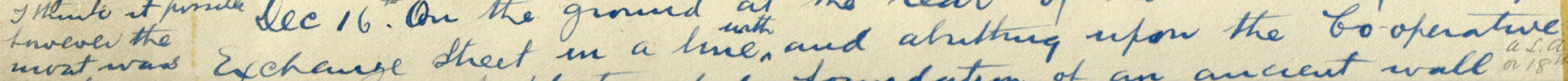

Figure 2.8: The opening sections of Joseph Himsworth's handwritten diary. The first entry is for $11^{\text {th }}$ October 1927 and records the discovery of the remains of Sheffield Castle. Courtesy of Pat Wagner.

in the back covers 'of my copy of Hunter's Hallamshire', thereby updating and developing (intentionally or not) some of the central concerns of the great antiquarian's account. Indeed, he continued to acknowledge his debt to Hunter, and in 1961 commissioned his daughter Joyce to make a plaque to commemorate the centenary of Hunter's death (Wagner 2012, 26; Figure 2.9). ${ }^{7}$ The last daily record in this section of the diary is for $20^{\text {th }}$ January 1928, and is followed by a reflective piece on the efforts being made to secure the preservation of the castle ruins, written two days later (we will return to these in Chapter 9). The second of the inside back covers contains seven photographs of the excavations by Himsworth, dated between $11^{\text {th }}$ October 1927 (his first day on site) and $18^{\text {th }}$ January 1928. Himsworth continued the diary (single-sided) on nine sheets of unlined paper, taped together and subsequently stuck between these back covers; the first dated entry is for $28^{\text {th }}$ September 1928. At the top of the first of these sheets, Himsworth wrote 'THESE NOTES ARE A CONTINUATION OF THOSE I HAVE WRITTEN IN MY COPY OF HUNTERS HALLAMSHIRE INSIDE THE BACK COVERS. J.B.H.' (Figure 2.10). Although Himsworth here refers to 'notes', he later calls his work a 'diary', and it does take the form of generally sequential dated entries.

7 The plaque was installed by the Hunter Archaeological Society while Himsworth was President in the Local Studies Library, Sheffield. 

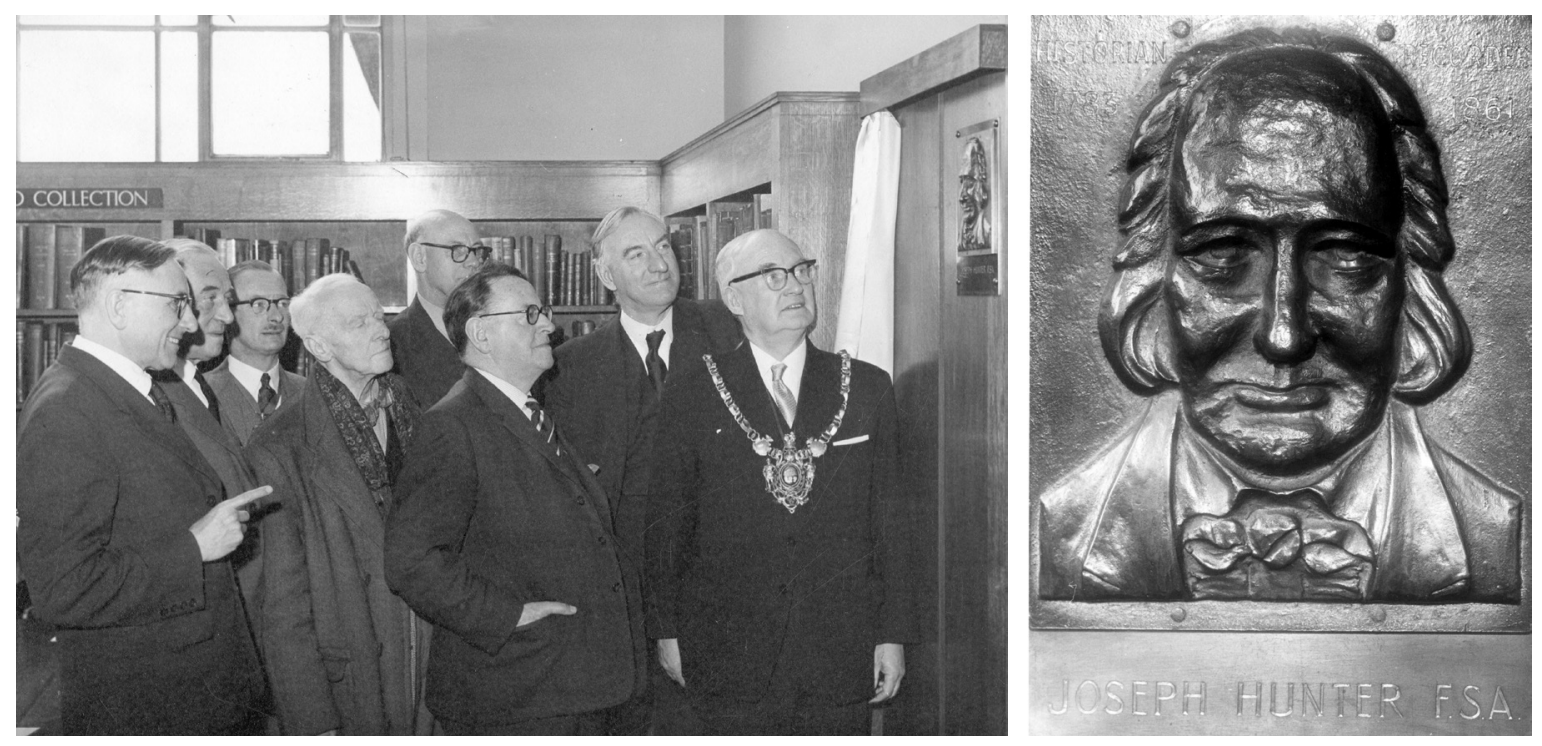

Figure 2.9: Joseph Himsworth, President of the Hunter Archaeological Society. Photographed (fourth from left) at the unveiling of a plaque in Sheffield Central Library to commemorate the centenary of the death of Joseph Hunter in 1961 (courtesy of Sheffield Newspapers Ltd (u08604)). This serves as a reminder of the powerful hold of the great antiquarian over studies of Sheffield's history (see also Figure 2.10). The plaque was made by Joyce Himsworth. With thanks to www.picturesheffield.com (s28138).

The second version of Himsworth's 'diary' is a typescript of the original, entitled 'Record by an eye-witness of the uncovering of SHEFFIELD CASTLE' (Himsworth 1927-42), contained within a green, fake crocodile skin binder (Figure 2.11). The inside cover bears 'An Old Sheffield rhyme', in the 'when Adam delved and Eve span' mode (Figure 2.7; see also below, Section: Himsworth's historical perspective), and on the following three pages are a copy of part of an inventory of the 'fitments and furnishings of the Castle at time of Mary, Queen of Scots' (from Tucker 1874), and two maps - one of the castle site as 'surveyed [in] 1889' at a scale of '41.66 feet to 1 inch', and one of the excavated area as depicted in plan I of Armstrong's 1930 excavation report. The text is accompanied by 49 illustrations, mostly Himsworth's photographs of the excavations and architectural fragments, but also sketches and section drawings. After the final typewritten entry, for $18^{\text {th }}$ February 1942, Himsworth $(1927-42,21)$ added the following handwritten note in blue ink:

As the whole of the Co-op building had perished in the blitz the large flat showcase full of small objects retrieved from the Castle site by excavation had disappeared. There were some of the objects also originally placed in Weston Park Museum.

J.B. Himsworth the compiler of this diary also has a few objects taken from the moat in his possession viz: an early shoe sole and several blades depicted by AL Armstrong in his report printed in the Hunter Archaeological Transactions (Figure 2.12).

At the bottom of the page he wrote, in black ink, a 'note of authentication', which, although undated, was probably written soon after the last entry: 'This typescript from my original daily notes and enlargements from my negatives are by courtesy of my friend C. H. Lea. JB Himsworth. Harry Lea was a Sheffield box manufacturer and, for a time, Honorary Treasurer of the Hunter Archaeological Society, well known for his photography skills, and may have introduced Himsworth to photography (Himsworth 1953, xi; Wagner n.d., 3). Himsworth travelled widely, and used the photographs he took to illustrate his public lectures - his talk to the Sheffield Artcrafts Guild on 'Personal Impressions of French Art Craftsmanship', for example, was described as 'splendidly illustrated, the photographs of cathedral and church architecture being exceptionally good' ('French art', 1922). As we will see, he put this expertise to good use as he recorded the uncovering of Sheffield Castle. 

IN.MYjuapen regardwig the sote for the manket; th he eneeted at the COPY. OF rear of the bu-of trildinig whech was to oecrepy the nemainis

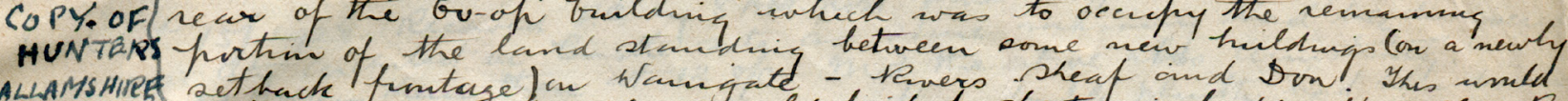

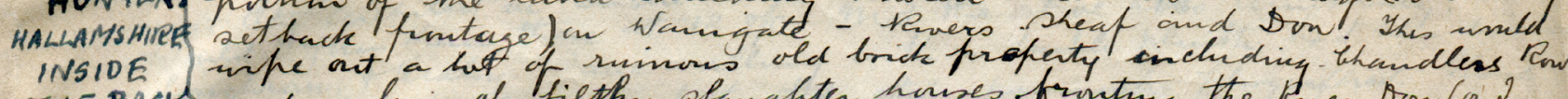
THE BACK

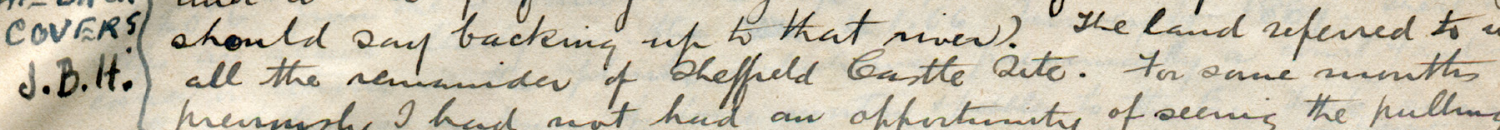

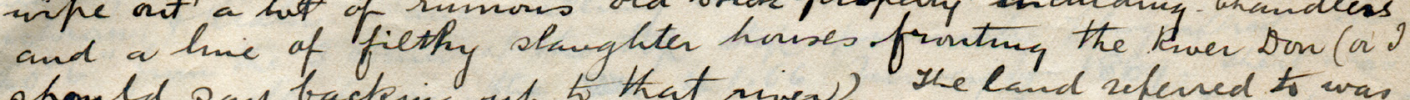

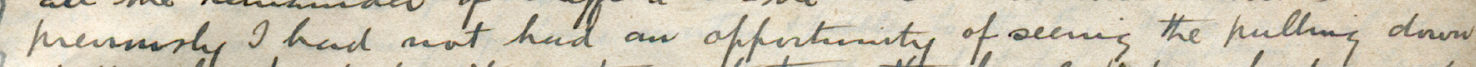

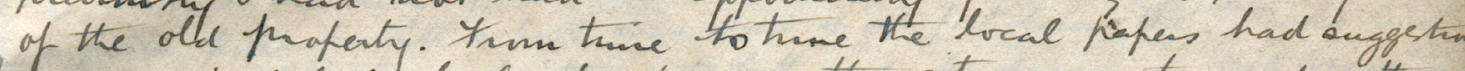

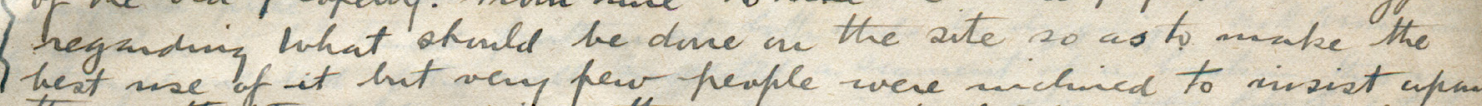

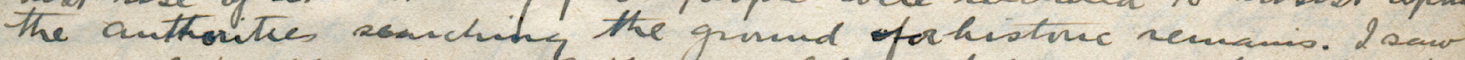

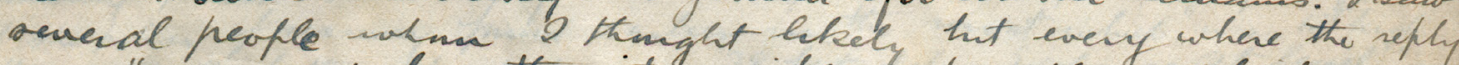
uns," we mint elewer the site quichly do frusuble bud hild a manket cheaply. Gunditwos of hade ane so trad we cas meither

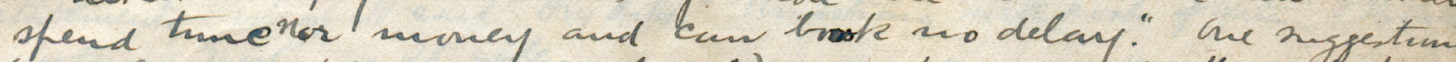
(and 2 hehure heass whe gut ont) was to excantale the site to

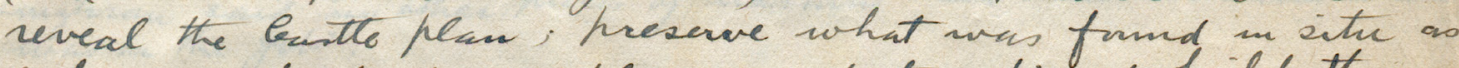
a hurenent, pasking place on what ruti and hild the maket wenhead an a level wath \&obange sheet.

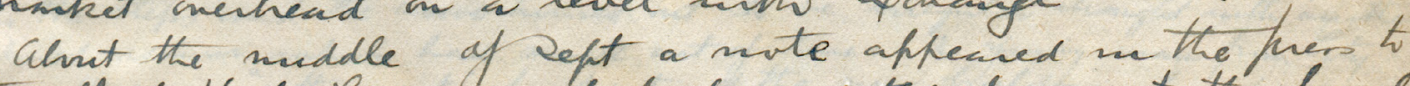

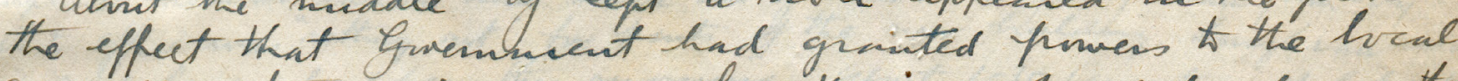

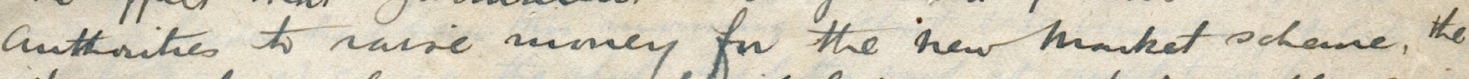

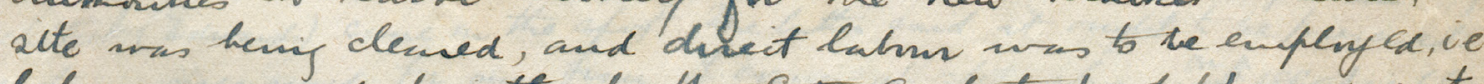
lahor engaged directhy hy the city archetects defut and not by enstractoos.

Sept. 28/28. Went drow m the sete-fund mot of the ald

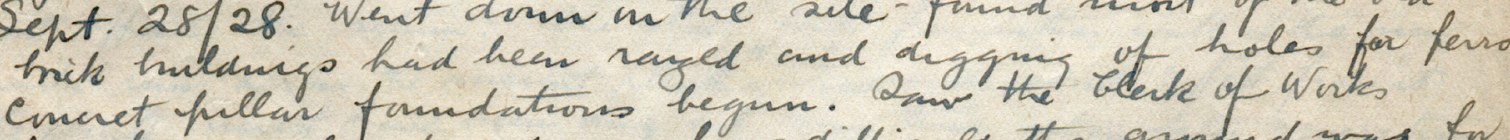

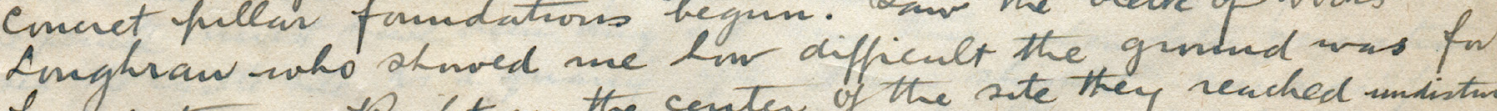

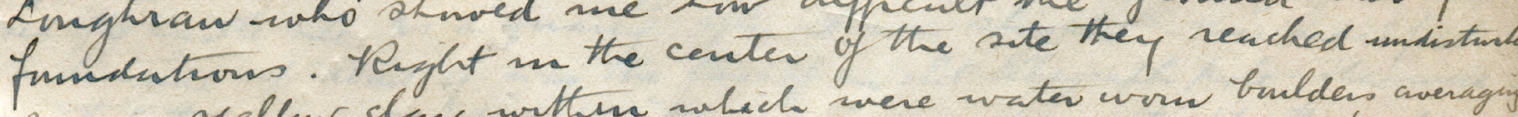

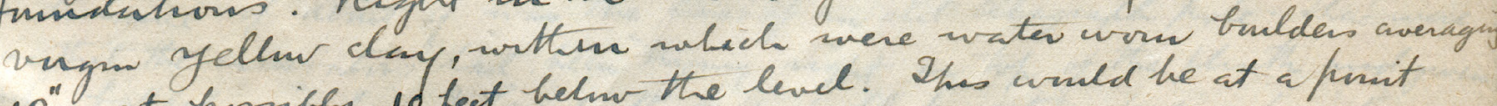
12". at prsibly of fect helw the level. The winded he at a hinit

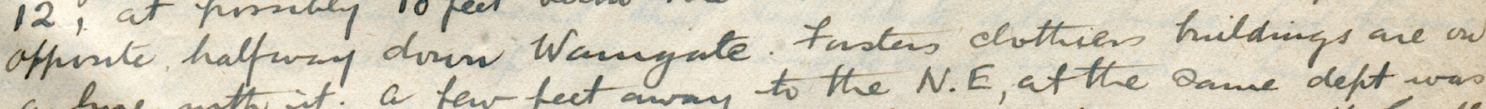
a have wo th it. a few fect oury to the N.E, at the Qane dept was

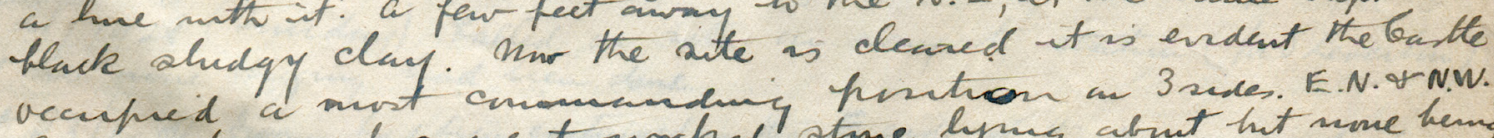

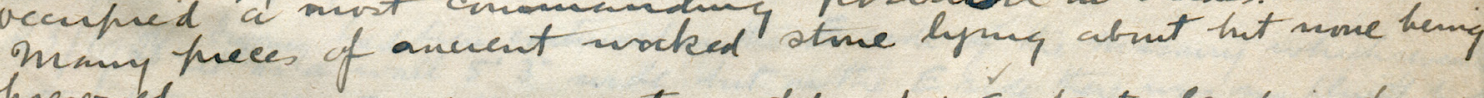

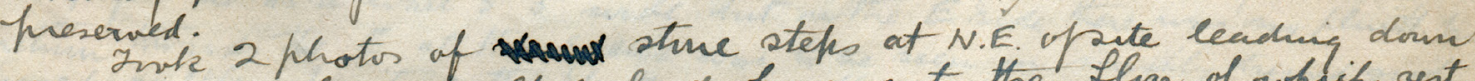

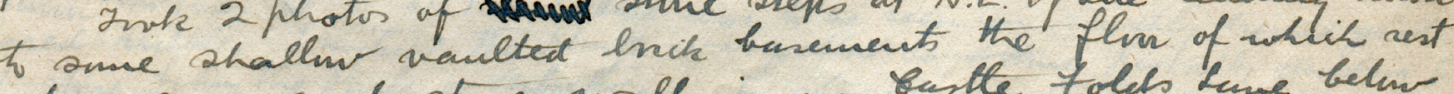

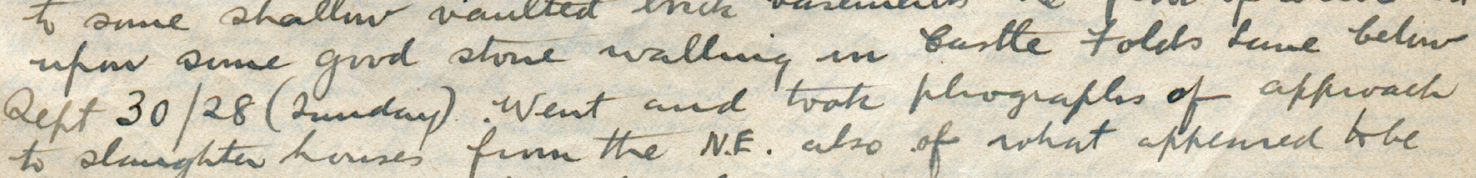
to slinghter huses fima the N.E. also of what ophened the

Figure 2.10: Himsworth's handwritten diary from $28^{\text {th }}$ September 1928. He records that 'These notes are a continuation of those I have written in my copy of Hunter's Hallamshire inside the back covers'. Courtesy of Pat Wagner. 

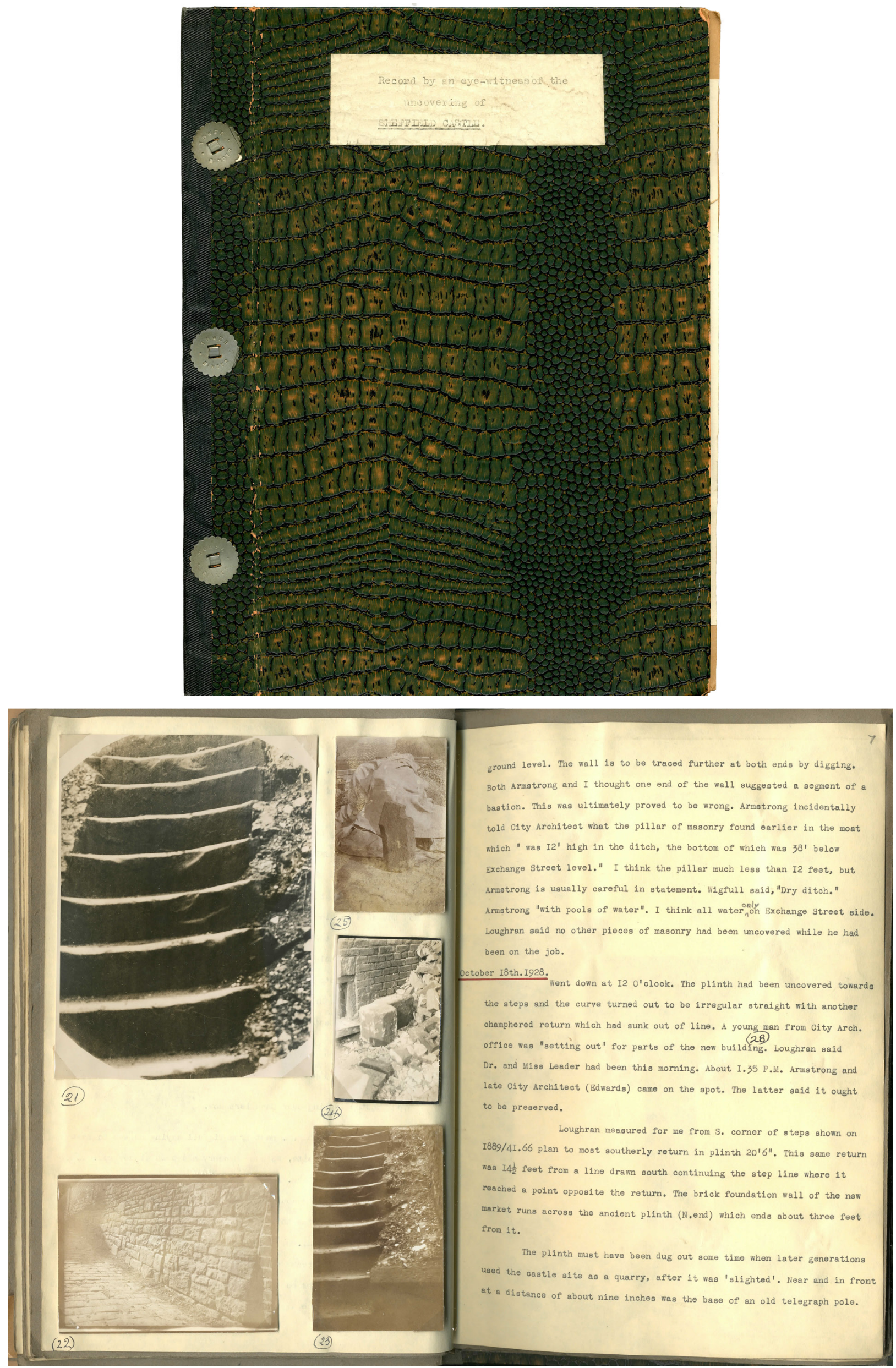

Figure 2.11: Record by an eye-witness of the uncovering of Sheffield Castle. Front cover of Himsworth's diary bound in fake crocodile skin (top); page of entries from 1928 and accompanying photographs facing (bottom). Courtesy of Museums Sheffield. 


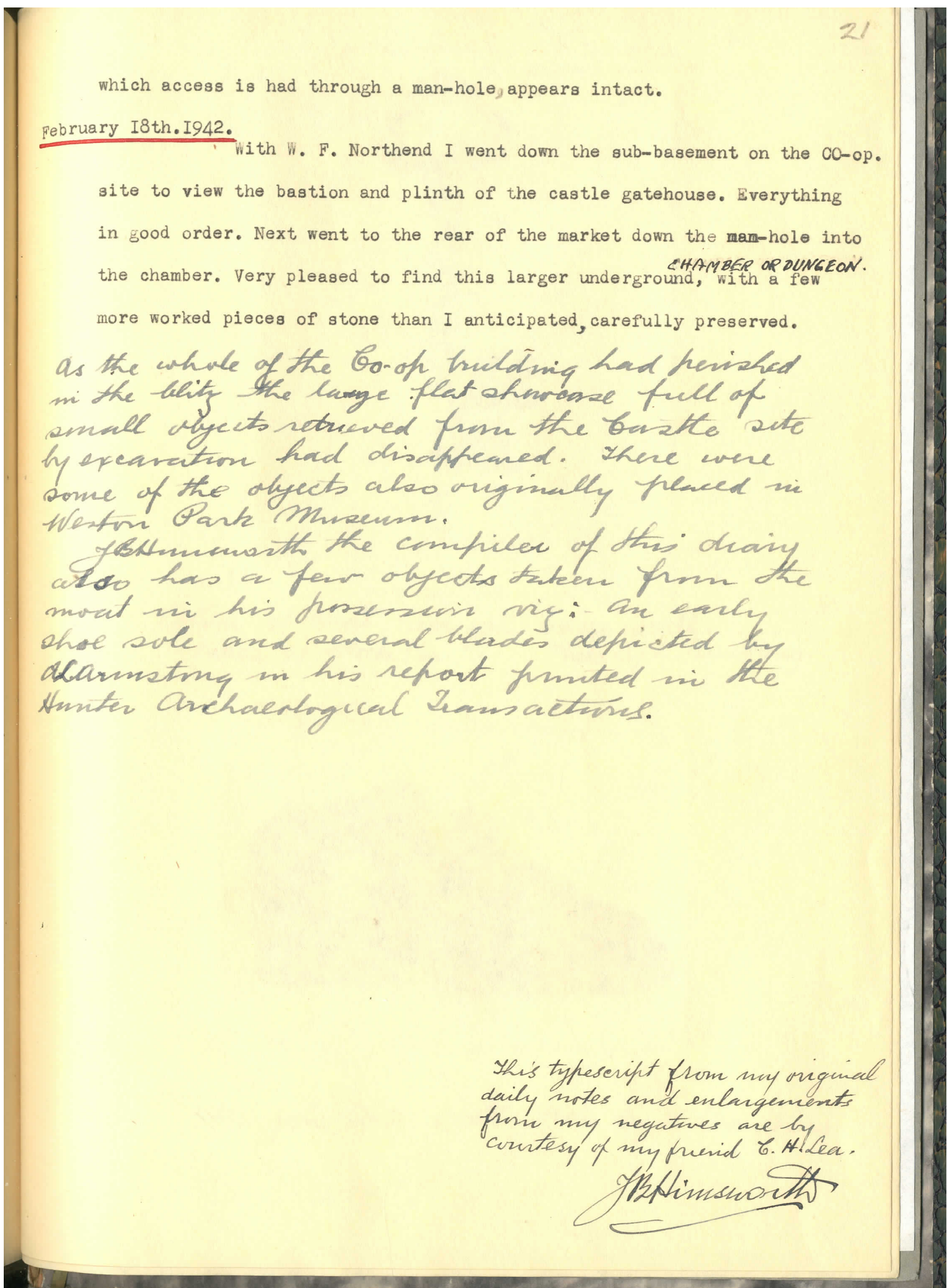

Figure 2.12: Last page of Himsworth's typed diary. A handwritten addition, reporting on the destruction of the Co-op building and the loss of some of the artefacts from the castle on display there. Himsworth notes that he has some items in his possession, and authenticates and signs this version of his diary. Courtesy of Museums Sheffield. 
Some editing took place in the process of turning the Himsworth manuscript into the typescript. For example, the manuscript entries for $21^{\text {st }}$ October 1928 ('(Sunday) Called on site on way to station (for S Leverton) but no more digging had been done') and $25^{\text {th }}$ October 1928 ('Called on the site - no developments') do not appear in the typescript, probably because they did not contain any significant information about progress at the castle. There are also some transcription errors; for example, $28^{\text {th }}$ December 1928 and $9^{\text {th }}$ September 1930 appear in the manuscript as, respectively, $8^{\text {th }}$ December 1928 and $4^{\text {th }}$ September 1930. Himsworth's final handwritten additions to the typescript are not found in the manuscript version, which also has a much more limited range of illustrations. For the most complete record we need both versions of the 'diary'. There is good evidence that the 'original' handwritten manuscript was not a day-by-day record. First, entries like that for $18^{\text {th }}$ November 1930 cannot have been contemporary - 'finishing the new road this week. It was later called Castle Gate' (Himsworth 1927-30, 1, emphasis added). Second, it has a very consistent and coherent feel - very cleanly presented and written in the same colour ink throughout the two main parts (blue for the part in Hunter's Hallamshire, and black for the continuation) - as if large sections were written in one go. This impression is reinforced by the correction of entries $-22^{\text {nd }}$ and $26^{\text {th }}$ February 1929 were changed to $22^{\text {nd }}$ and $26^{\text {th }}$ March - which might well occur if entries were being copied out from another source.

That the manuscript was not a continuously maintained, contemporary record of events is confirmed by the last entries, in which Himsworth returned to it after a gap of more than 10 years to record that on the night of $12^{\text {th }} / 13^{\text {th }}$ December 1940 'The Co-Operative Stores destroyed by blitz', by $13^{\text {th }}$ February 1942 'a good deal of the debris has been removed from the site, and on $18^{\text {th }}$ February 1942 he visited the excavated remains with W. F. Northend and found 'everything in good order'. Each of these entries is 'distinctive' - in terms of writing style or ink colour - and so stands in contrast to the general uniformity of the preceding entries. Further, the original Himsworth manuscript was accompanied by three pages of what looks to be his personal diary/ account book, covering $14^{\text {th }}$ July to $20^{\text {th }}$ August, and $30^{\text {th }}$ October to $5^{\text {th }}$ November 1930 . They contain only three daily entries, as well as two sketch sections. Of the daily entries, that for $19^{\text {th }}$ August is most illuminating - 'Demolishing retaining brick wall on castle site. 5 to 6 feet down comparatively recent filling only revealed' (Himsworth 1927-30; Figure 2.13). The relevant entries in both the manuscript and typescript diaries match (almost) perfectly: 'Today they are demolishing brick retaining wall under castle bank. 5 to 6 feet down recent filling only revealed' (Himsworth 1927-30; 1927-42, 17). Some of the sketches stuck into the manuscript were drawn on pages of what appears to be the same diary.

Himsworth recorded his work on the castle elsewhere too. The Museums Sheffield archive contains a single sheet of lined paper, embossed at the top with Himsworth's address, on which he wrote the following:
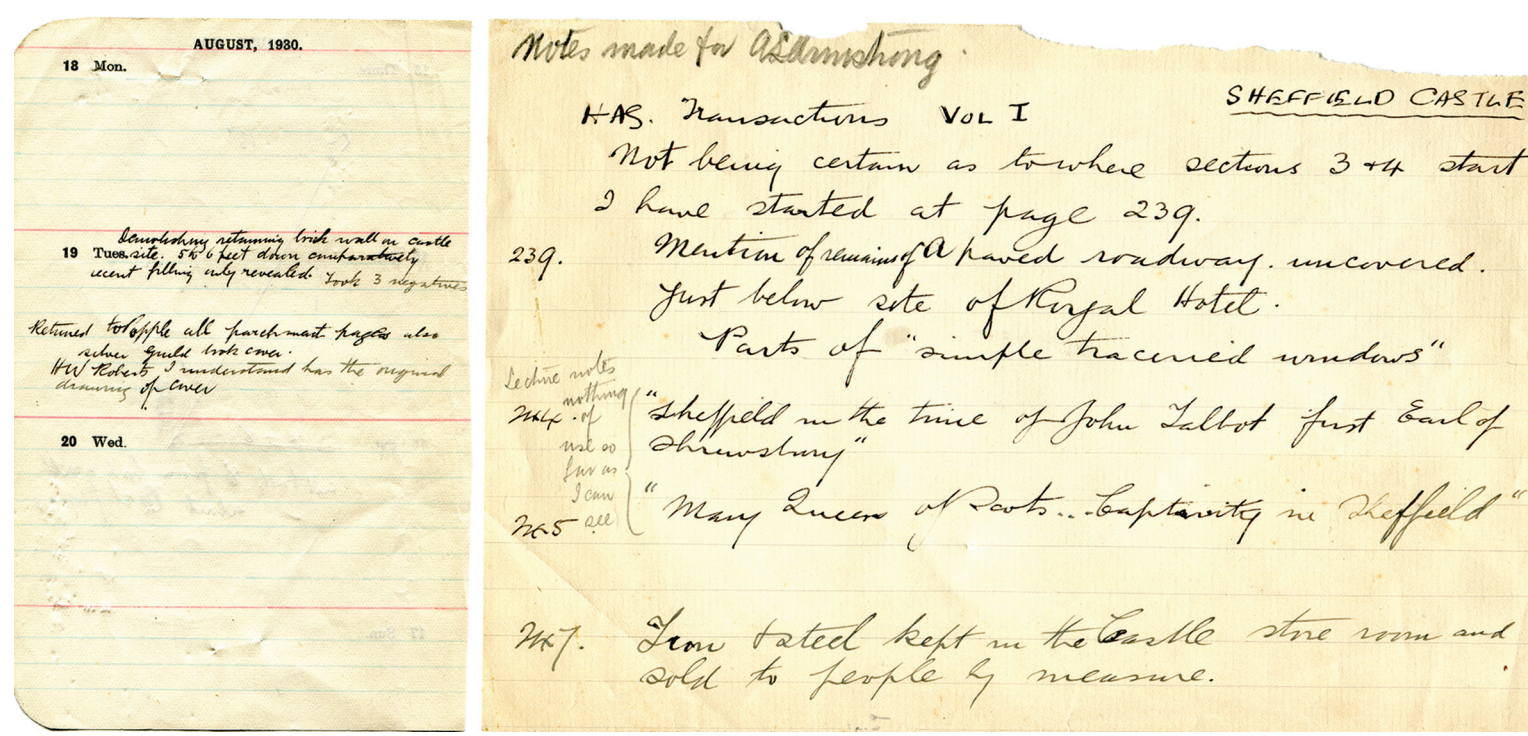

Figure 2.13: Joseph Himsworth's entry in an account book recording the demolition of the retaining wall above the Don in August 1930. This was subsequently copied into his diary (left). Notes on historical research (right), also by Himsworth. Courtesy of Pat Wagner. 
I met Mr Austin. Messrs. Bagshawe \& Bradbury were both out of town.

Friday

Concreting round the pier was starting while we were there at 12-30. today (Himsworth n.d. (d))

This note almost certainly served as an aide-memoire for the diary entry for Friday, $20^{\text {th }}$ January 1928 :

Met John Austen on the site ... Found the foundation of the pier had been cleared of sludge ... They were then putting concrete into the hole, the foreman remarking upon the fact that the splendid stonework of the pier was a good support for their concrete (Himsworth 1927-42, 3).

So, before Harry Lea typed up the 'Record by an eye-witness' 'from my original daily notes' (Himsworth 1927-42, 21, emphasis added), it seems that Himsworth first copied his personal diary entries and other notes into the manuscript we have now. We have taken some time to outline the origins and history of the diary as it is a crucial, largely untapped, resource and will play a significant part in detailing exactly what was found of Sheffield Castle between 1927 and 1930 in the next chapter.

\section{Armstrong's assistant?}

In his 1935 lecture to the Sheffield Trades Technical Society, Himsworth $(1935,5)$ told the audience that following his appointment by the Hunter Archaeological Society to 'watch the excavations ... Mr Armstrong very kindly allowed me to act as his assistant', and in another lecture stated that Armstrong 'was good enough to allow me to make myself conversant with all that occurred in detail' (Himsworth 1937, 5), perhaps because of the depth of his knowledge of local history, as there is no evidence that he had any significant archaeological experience. Whatever the case, our archival research has enabled us to determine something of Himsworth's remit as 'assistant', and to chart the process by which he came to assume increasing responsibility for overseeing the excavations.

Himsworth does not seem to have been involved on site from the very beginning. It was not until October 1927, when the first traces of what were believed to be Sheffield Castle were uncovered (Armstrong 1930, 14), that we have evidence of his involvement. The first entry in his 'Record by an eye-witness' account is dated $11^{\text {th }}$ October 1927 and Himsworth $(1927-42,1)$ tells us that he

met A. Leslie Armstrong and J.R. Wigfall [recte Wigfull] on the site of Sheffield Castle, Exchange Street, where masonry, i.e. walling, both straight and round in plan; both sections having a good plinth had been uncovered when a trench was excavated for the back wall foundations for business premises (Brightside and Carbrook Co-operative Society; Figure 2.8).

In his 1935 lecture Himsworth $(1935,6)$ conveys more of the excitement of the moment, telling his audience that 'on October 11th 1927 I got a message from Armstrong by phone to "come down at once a most astonishing discovery has been made". He also told them that he 'photographed daily' the uncovering of the drawbridge pier, thereby providing further insights into the depth of his involvement in the project and into some of his duties as 'assistant' to Armstrong. Although it was mainly the photographs of 'Mr Senior, of the Improvement Surveyor's department' that were used to illustrate the 1930 paper (see Armstrong 1930, 37; Himsworth 1927-42, 11), Himsworth's images, preserved in his 'Record by an eye-witness' and elsewhere in the Museums Sheffield archive, provide invaluable insights into both what was found, and under what circumstances - into how archaeology was done in the 1920s.

Another of Himsworth's duties as assistant was to carry out background research on the site and the castle. An undated slip of paper included with Himsworth's (1927-30) 'THE UNCOVERING OF SHEFFIELD CASTLE SITE' manuscript is headed 'Notes made for Armstrong', which derive from articles in volume 1 of the Transactions of the Hunter Archaeological Society (1914-18), and are directly referenced in Armstrong's $(1930,13)$ paper (Figure 2.13). Furthermore, Himsworth's (n.d. (a)) notes on Hunter's Hallamshire (Gatty's updated 1869 edition) seem to have informed Armstrong's $(1930,8)$ description of the castle c.1646. Here Himsworth was acting much as a modern-day 'research assistant', and Armstrong $(1930,27)$ acknowledged his 'help ... during the preparation of this report' - but he went on to become so much more than this. As Armstrong became preoccupied with the serious illness and death of his wife on $19^{\text {th }}$ January 1928 ('Deaths', 1928; Himsworth 1927-42, 3; Butcher 1961, 7), and then took a career shift away from Sheffield (below, 
Section: The enduring legacy of Leslie Armstrong), the diary suggests that Himsworth assumed more responsibility for observing the construction of Castle Hill Market and recording the archaeology brought to light (see also Butcher 1972a, 3).

The final 'daily' entry in the first part of the diary records that on $20^{\text {th }}$ January 1928 Himsworth was on site but 'Mrs. Armstrong had died and A.L.A. could not be present'. The break in the diary at this point might well be a product of Armstrong's tragic personal circumstances, combined with the fact that the digging of foundations for the construction of the Brightside and Carbrook building had been completed, and with that the need for an archaeological 'watching brief' had ended.

The diary resumes on $28^{\text {th }}$ September 1928 with an overview of the efforts in the preceding months to preserve and display the excavated remains. This probably coincides with the resumption of excavations associated with the construction of Castle Hill Market. From this point on Armstrong appears less frequently in the diary entries, and sometimes in a more 'passive' role, with Himsworth, by contrast, seeming to take a more active part, for example in discussions with Reg Loughran, the Clerk of Works. Thus, in a series of entries from mid-October 1928, we read of Loughran assisting Himsworth in measuring the site (1 ${ }^{\text {th }}$ October), showing him 'his plan upon which was indicated the bastion and plinth discovered last autumn' (23 ${ }^{\text {rd }}$ October) and deploying some of his workmen to help Himsworth explore parts of the site ( $31^{\text {st }}$ October). On $7^{\text {th }}$ December 1928, Himsworth 'phoned A.L.A. to come down' to see a newly uncovered section of the plinth 'in perfect state. A very handsome piece of masonry' (Figure 2.14). Armstrong said 'he would do so at 3-30'; Himsworth,
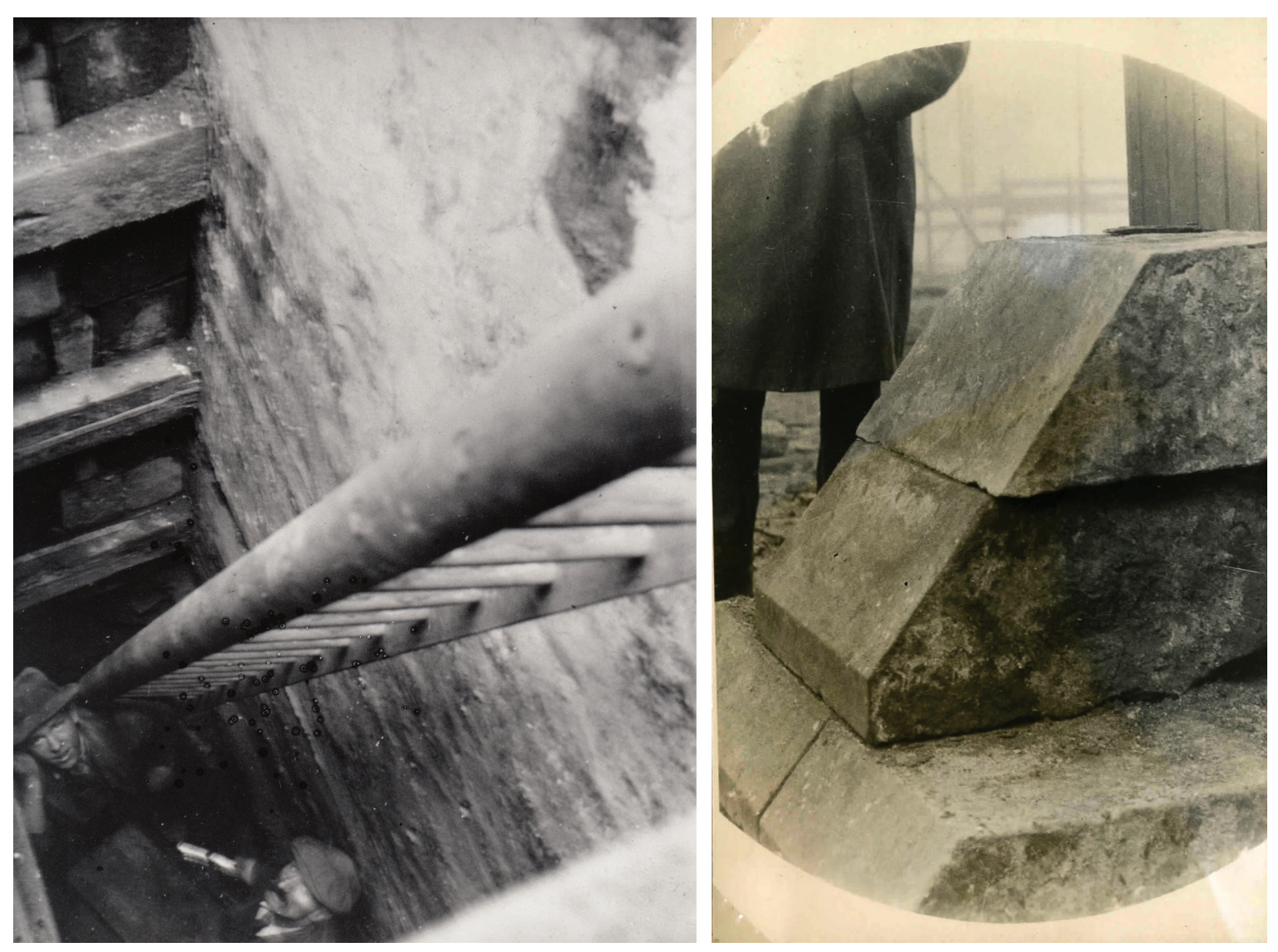

Figure 2.14: Photographs taken on $7^{\text {th }}$ December 1928 when a section of plinth was found in a foundation shaft. At the bottom of the shaft (left) are Joseph Himsworth and one of the construction workers, probably the Clerk of Works Reg Loughran since Himsworth $(1927-42,12)$ recorded that he 'went down the hole with him'. On the right is the plinth after it had been removed from the shaft. Courtesy of Museums Sheffield. 
meanwhile, 'went down the hole' with Loughran. Yet, Armstrong was still involved - on $20^{\text {th }}$ December 1928 Himsworth reports that 'A.L.A called and said he had seen in one of the holes got out for a pillar there were nine "occupation levels" in ten feet'. Indeed, Armstrong was clearly still in charge - when the editor of the Sheffield Independent Press called Himsworth on $28^{\text {th }}$ December 1928 to ask if he could use some of his photographs of the excavations, he 'referred him to A.L.A.' (Himsworth 1927-30, 3).

The diary breaks again on $4^{\text {th }}$ April 1929 , probably marking roughly the point after which no more excavations were necessary for the construction of Castle Hill Market. Armstrong left England with his son on $10^{\text {th }}$ May 1929 to lead the Rhodesian Archaeological Expedition to Southern Rhodesia, returning in September (Armstrong 1931, 239; Allsworth-Jones 2014). The only two entries between then and late June 1930 probably represent special visits to the site. In the first (12 ${ }^{\text {th }}$ August 1929), Loughran showed Himsworth how they had preserved various important features (see below) 'by making a basement' (subsequently referred to in the present volume as the chamber for the courtyard remains), and in the second ( ${ }^{\text {th }}$ September 1929) Himsworth photographed the area cleared for 'a new road' by the demolition of the slaughterhouses. From $24^{\text {th }}$ June to $18^{\text {th }}$ November 1930 he records features revealed during construction of this 'new road', which do not appear in Armstrong's publication, including the remains of what he thought were four towers on the northern curtain wall overlooking the Don, and decorative mouldings and tracery, at least some of which was 'probably Grenoside sandstone' (Himsworth 1927-42, 18-20; Figure 2.15; see also Chapter 7). He also recorded the digging of holes to be filled with concrete to 'stiffen the edge near the river bank' of the Don, which revealed the underlying
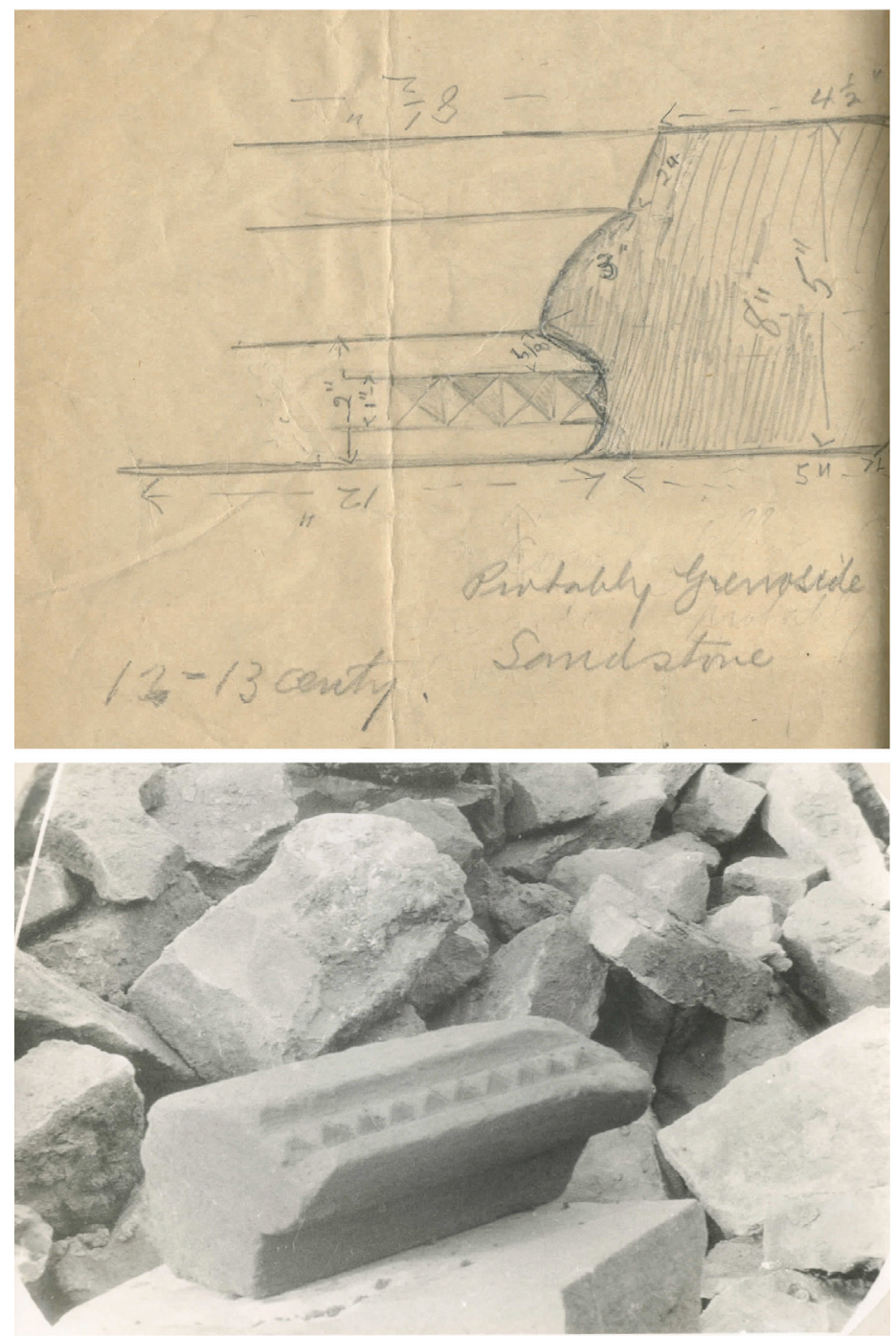

Figure 2.15: A piece of decorative moulding of Grenoside sandstone found on 17th October 1930. The sketch on the top is by Himsworth and was incorporated in the typed version of his diary. Courtesy of Museums Sheffield. 
geology (Himsworth 1927-42, 16-17; also Butcher 1972a, 4). The break in the diary after this point marks the end of construction. It seems that Himsworth had 'graduated' from being Armstrong's on-site assistant and had taken on responsibility for observing, and recording, the archaeology of Sheffield Castle. As Leslie Butcher (1972a, 4) later noted, Himsworth comes across as 'a dogged observer', endeavouring to record the remains of the castle 'on a site still encumbered with undemolished walls and slopes of rubble', the admiration evident in Butcher's remark probably a product of the fact that he himself had recently faced the same difficulties of 'doing archaeology' in a construction environment (see Chapter 4).

\section{Himsworth's historical perspective}

Himsworth's diary and lectures provide us with very personal insights into the archaeological interventions on the site of Sheffield Castle in the late 1920s. The lectures especially reveal the historical perspective through which he approached the past and read its evidence. His was a rather variegated, and subtle, philosophy of history, informed by intellectual perspectives perhaps drawn from, and certainly in harmony with, his social and political beliefs. The importance of the power of the past underpinned his historical understanding - 'what has happened in the past still shapes and influences what will be'. And for Himsworth those 'happenings' could take the form of natural processes as well as human actions: 'geological deposits, geographical position, climatic conditions have all helped to make our district what it is, and incidentally helped no doubt to produce that rather unusual type of individual "the Sheffielder"' (Himsworth 1937, 1; see also Armstrong 1942, 30 for a similar emphasis on the environment as a 'potent factor' in cultural evolution). 'Sheffields [Sheffield's] course', Himsworth went on to tell the audience attending his lecture on '500 Years of Sheffield Trade and Sheffield Castle', was shaped by 'Geographical position natural resources, and industry started by the monks locally' (the latter referring to the role of monastic institutions in initiating, and then developing, metalworking industries in the region; Himsworth 1937, 4). Reflecting on the relationship between long- and short-term history, between structure and event, Himsworth $(1937,4)$ argued that not only did the environment and past history of the region influence the character of the people of Sheffield and its castle, but in its turn that 'Castle and its occupants have, like destiny "shaped our ends rough hew them as we will"'. Himsworth is here quoting from Hamlet (Act V, sc. ii, 1l. 3659-60), but, given his inclination towards the ideals of the early Bolsheviks (Wagner n.d., 2), he might as easily have cited Marx's (1963, ch. 1) famous dictum that

Men make their own history, but they do not make it as they please; they do not make it under selfselected circumstances, but under circumstances existing already, given and transmitted from the past. The tradition of all dead generations weighs like a nightmare on the brains of the living.

In the same lecture, Himsworth $(1937,4)$ extended his thoughts on the relationship between past and present by comparing the Norman Conquest with 'the recent terrible [Italian] conquest of Abysinnia' (October 1935-May 1936). There are signs that he believed that 'historical imagination' might be used to bridge the gap between past and present and facilitate interpretation of the archaeological and historical records. This might take the form of imagining himself witnessing, and thus understanding, past events at Sheffield Castle. Reading Hunter's Hallamshire, for example, 'especially did I [he] feel sorry' for his namesake, Gabriel Hemsworth, one of those appointed to negotiate the surrender of the castle to its Parliamentarian besiegers in August 1644 (Wilson MSS 295/24 fol. 8):

The terms recorded were generous and I pictured him marching out as is permitted in the terms drawn up with 'the Governor and all the other officers, with their drums and colours, and each his own horse saddled; sword and pistol, to Pomfret [Pontefract] Castle or wheresoever they please' (Himsworth 1935, 1; see also Himsworth 1944, 2; Hunter 1819, 111).

As well as using a possible genealogical connection to imagine himself back into the colour and spectacle of that historical moment, ${ }^{8}$ Himsworth (certainly influenced by the craft tradition within which he worked)

8 'These references to ancestry are sometimes dangerous as you know - it just depends how far you push the matter' (Himsworth $1935,1)$. 
also used the objects, and the site itself, to enter into the immediacy of everyday life in the past. Having described the discovery and excavation of the castle moat, he then asked his 'Some Old Sheffield Stories' audience to

Just try to imagine what would be likely in times past to occur at this spot. Here with the gateway towers overlooking the moat what a handy place to throw all the rubbish. Antlers \& bones from the kitchen, broken knives \& keys, and other unmendable articles. Old shoes of several periods, hundreds of years old were discovered in quantities, some with a hole worn through the sole where the big toe had contacted the ground most strongly (Himsworth 1935, 6-7).

We get the same sense of entering the past through an engagement with the immediacy of its material remains at the beginning of his 'Eye Witnesses of Sheffield Castle' lecture. Explicitly setting to one side the perspective of 'owners', he found his 'eyewitnesses' in 'documents written by those who saw things in their settings for daily use' and in 'objects which may be seen and handled today' (Himsworth 1944, 1). He undoubtedly used his knowledge of both to imagine, and to sketch out a picture of, the life of the family of a 14th-century 'peasant cum-handicraft worker. They would have lived in a

crucks built house of huge beams divided in three sections and [would have carried out] the comparatively easy provision of food by growing on a small scale a little corn, some vegetables and keeping a pig or a cow ... each household trying to be as self supporting as possible (Himsworth 1937, 3a).

While this is clearly an idealised vision of a self-sufficient family (and community), it does reveal that, although Himsworth's historical understanding was framed by great men and events, his historical instinct was to seek out the 'common man'. What we might call his nostalgic egalitarianism is evident in the 'Old Sheffield Rhyme' recited to him by 'J. Wragg' (did he mean James Ragg Wigfull?), which he uses to preface his 'Record by an eyewitness' (Figure 2.7), and repeats at the end of its first section (Himsworth 1927-42,4) and at the beginning of the typescript of his 'Some Old Sheffield Stories' lecture $(1935,1)$.

Himsworth's historical method involved using empathy and imagination to link together and extract meaning from the 'facts' found in objects and texts. In this sense, his approach might be said to come close to that advocated, at roughly the same time, if in very different circumstances, by R. G. Collingwood (Waynflete Professor of Metaphysical Philosophy at the University of Oxford):

the historian's picture of his subject, whether that subject be a sequence of events or a past state of things, thus appears as a web of imaginative construction stretched between certain fixed points provided by the statements of his authorities; and if these points are frequent enough and the webs spun from each to the next are constructed with due care, always by the a priori imagination and never by merely arbitrary fancy, the whole picture is constantly verified by appeal to these data, and runs little risk of losing touch with the reality which it represents (Collingwood 1994, 242; also Johnson 1998, 79-90).

Joseph Himsworth was a craftsman and cutler, a skilled professional. But, like many people in the Sheffield in which he grew up who were influenced by Morris and Ruskin, he had strong political and historical sensibilities (see Rose 2001, 190-6). As we will see in the section that follows, this was a combination that would significantly advance the study and understanding of Sheffield Castle.

\section{Doing archaeology in Sheffield 1927-30}

As we have seen, neither Armstrong nor Himsworth was a professional archaeologist - although the former was the vastly more experienced of the two. They were, as Barri Jones $(1984,10)$ put it, amateurs who 'earned their daily bread elsewhere', which had a significant impact on the nature of their archaeological practice. Himsworth joined his father's cutlery firm of B. Worth \& Co. in 1888, initially 'to do office and warehouse work' (Himsworth 1965; Museums Sheffield 2019a), and Armstrong worked full-time for the Inland Revenue while monitoring the excavations on Castle Hill. They were working at a time where urban archaeology, if it 
existed at all, took the form of the exploration of the remains of the cities of Roman Britain - an extension onto home territory, Martin Carver $(1987,101-3)$ argues, of the archaeological 'pursuit of the lost Homeric and biblical cities of the eastern Mediterranean', exemplified at exactly the same time by Sir Leonard Woolley's excavations at Ur (Mesopotamia, modern Iraq). This was a time, Carver $(1987,102)$ continues, of wholesale destruction of archaeological deposits and buildings 'to which the blitz in many cases put the finishing touches': a time when, in many places, the physical fabric of past urban dwellers was considered 'nothing but a nuisance, to be got rid of at the first convenient opportunity' (W. T. Jones on the 'walls and towers of Durham' in 1923, cited by Carver 1987, 102). Armstrong and Himsworth were largely not in a position to do other than observe such destruction and to record the strata, objects and buildings it brought to light. And they owed this concession to 'the Directors and Mr. J. E. Forster, the Secretary, of the Brightside \& Carbrook Co-operative Society', who, as we have seen, granted 'permission to watch the excavations', and to 'Mr. W.G. Davies, F.R.I.B.A., the City Architect ... for assistance given and privileges accorded in relation to the excavations on the site of Castle Hill Market' (Armstrong 1930, 27).

Photographs taken on site at the time capture the energy and 'chaos' of an active construction site, revealing just what a difficult task Armstrong and Himsworth faced in attempting to record the archaeology of Castle Hill (Figure 2.16). In what must have been one of the first public announcements of what he had observed,
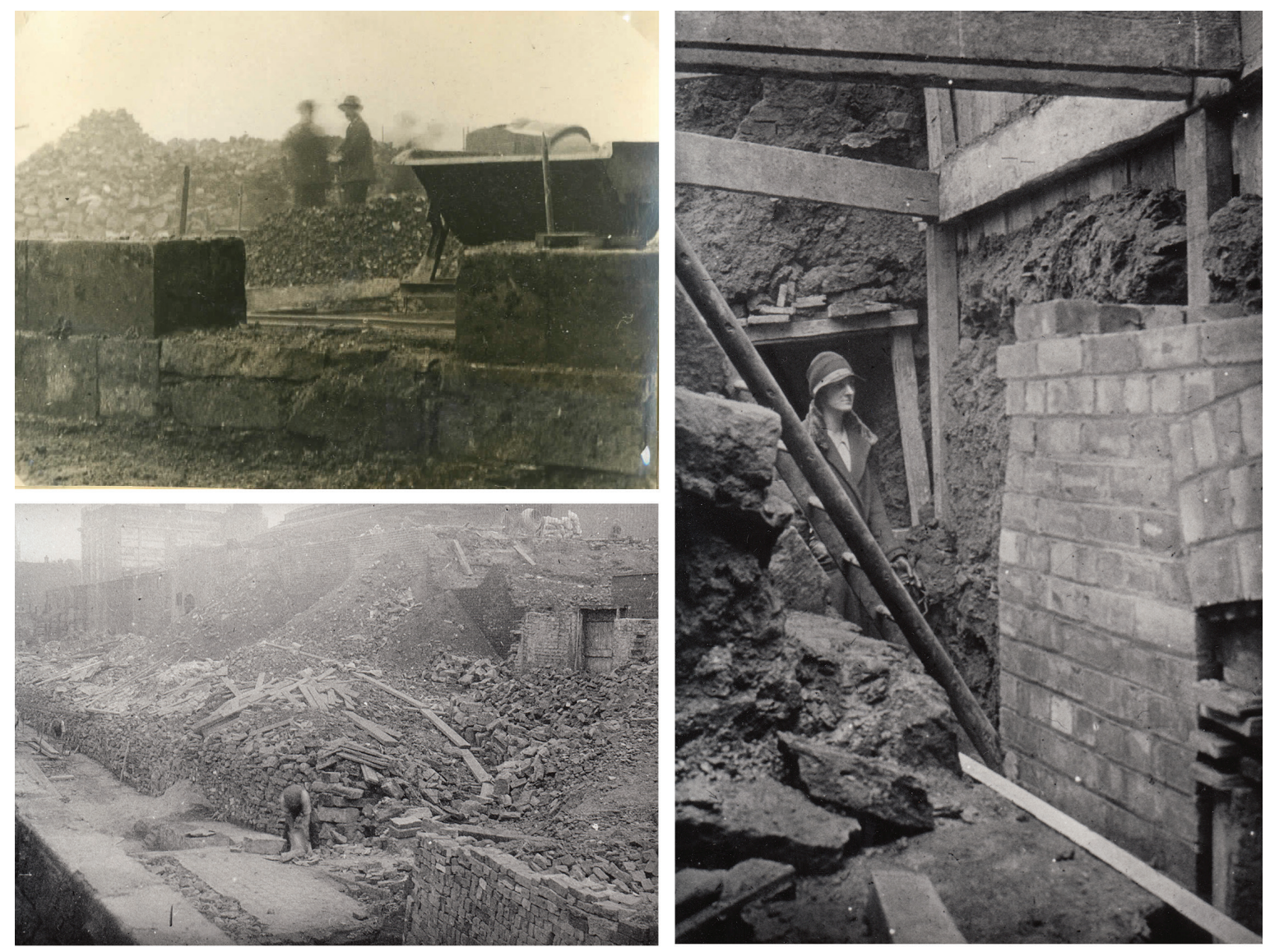

Figure 2.16: The site of Sheffield Castle during construction work 1927-30. Armstrong and Himsworth experienced considerable difficulty recording archaeology on an 'active' construction site. The right-hand photograph shows the wattlework believed to be Anglo-Saxon (next to the woman's hand), which is discussed in Chapter 3. This photograph appeared in Himsworth's diary along with the top left-hand photograph showing construction work near the courtyard buildings, with a planning frame placed on the walls of one of these buildings for a foundation shaft to be dug there (see also Figure 3.17). The bottom left photograph records building work in 1930 at the north of the site above the Don before Castlegate was built. Courtesy of Museums Sheffield. 
a report Armstrong (1927b) wrote for a local newspaper, The Star, in late October or early November 1927, makes clear how the presence of the castle remains affected the ongoing building work (Figure 2.17). Thus, he describes how the construction teams experienced 'considerable difficulty' finding a firm foundation for the wall of the new Co-op building, as their trial shaft just kept going down, 'deeper and deeper', through sticky black sludge. We now know, as Armstrong later concluded, that this was the fill of the moat - at the time he thought it could equally have been a rubbish pit (Armstrong 1927b). Early 19th-century construction on the site of Liverpool Castle faced a similar problem, and the builders 'having met with the filled in moat ... thought it necessary to excavate it to the bottom to obtain reliable foundations', resulting in basements reaching $23 \mathrm{ft}$ (7.01m) below street level (Larkin 1927, 183-4).

Both this 1927 newspaper report and his 1930 paper reveal Armstrong's irritation with the attitude of the construction workers, who were only minimally engaged with what he was trying to do (maybe they too thought him 'troublesome'!):

Though a bonus was offered for all finds, the men were not sufficiently keen to look out for objects of interest until stimulated by the finding of [a 'silver'] key ... near the bottom of the ditch. It is certain that

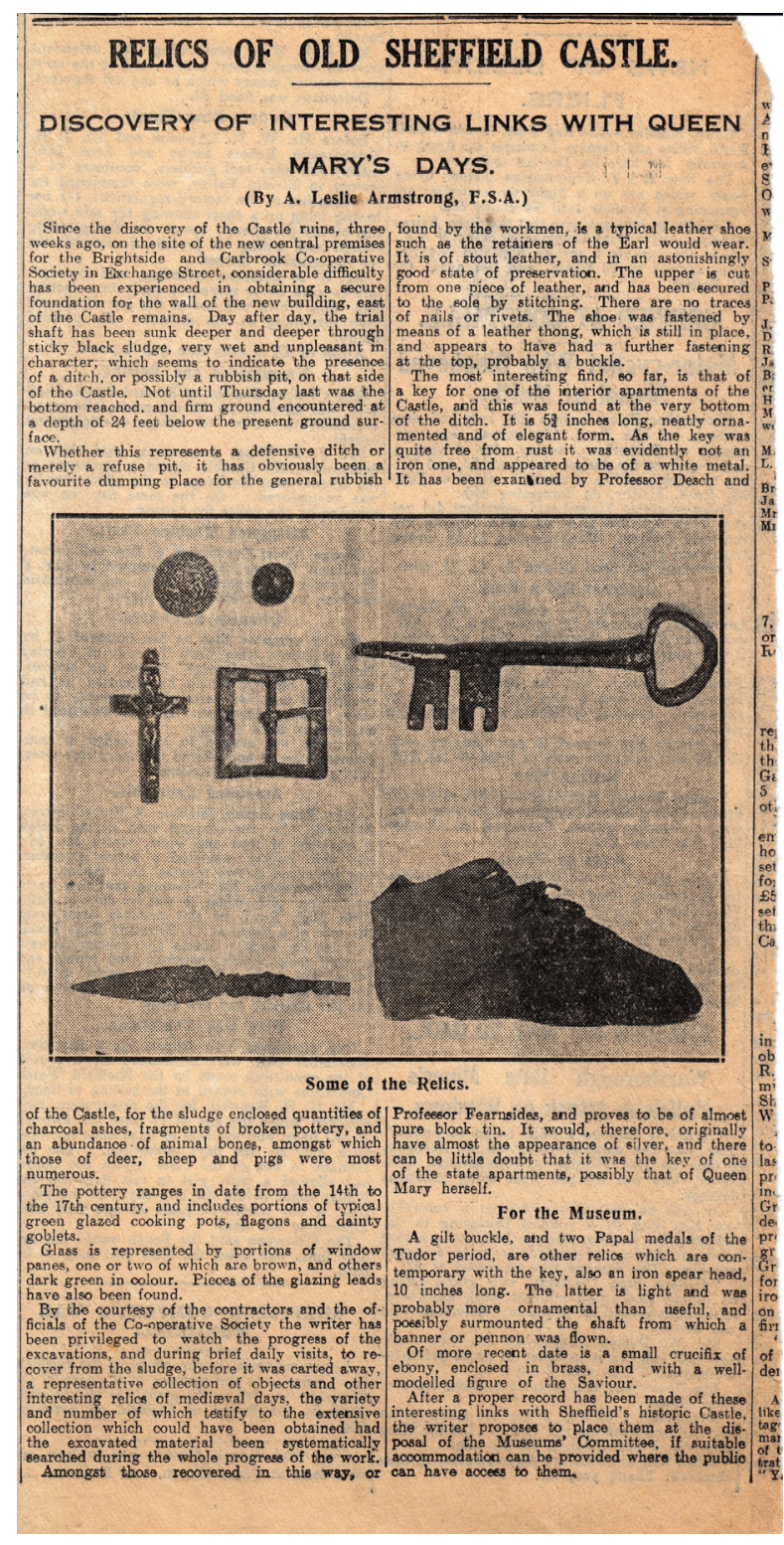

Figure 2.17: Newspaper article about the findings on Castle Hill from 1927. This was one of the first published accounts of the ongoing excavations. In his report Armstrong stressed the difficulty of the working conditions and also made the link with Mary, Queen of Scots. Here he was appealing to public interest in a well-known period in Sheffield's history, although he had little to say about the Queen in his published work and clearly knew that the key was not 'that of Queen Mary herself'. Courtesy of Museums Sheffield. 
this rich section would have yielded much more had it been possible to give the work constant supervision and to examine the whole of the material before it was carted away to the tip (Armstrong 1930, 15).

It is possible, such was Armstrong's frustration with the disengaged workmen, that, in his efforts to motivate them he was economical with the truth about this key. In his 1927 newspaper article he suggested that 'there can be little doubt that it was the key of the state apartments, possibly that of Queen Mary herself'. However, on the back of one of the original photographs he describes it as ' $14^{\text {th }}$ Cent. key of one of the state apartments' (Armstrong 1927a; also 1930, 25) - long predating, therefore, the incarceration of the tragic Queen of Scots (Moreland and Gorman 2019). Armstrong was not unusual in associating objects with a notable local figure; for example, in the same period at Knaresborough (North Yorks) a 13th-century cooking pot was embellished by public opinion which claimed it held 'the incinerated remains of the local Saint Robert' (Barber 1931, 202).

In his diary Joseph Himsworth appears even more frustrated than Armstrong with the apparent lack of concern for the archaeology of the site shown by the site foreman and labourers. For example, on $11^{\text {th }}$ December 1927 he 'called on the site to find the contractor had concreted the excavation, burying the plinth or tower and several courses of masonry' (Himsworth 1927-42, 2), and in January 1928 lamented that 'Up to the present there has been more destroyed or covered up with concrete than will ever be seen by the public' (Himsworth $1927-42,4)$. On $28^{\text {th }}$ September 1928 he noted that, although many pieces of 'ancient stone' were lying around, 'none [were] being preserved' (Himsworth 1927-42, 6). In December of that year, when architectural fragments were encountered during digging close to the north wall of the Co-op building, he remarked that Loughran 'was cursing the delay these finds were causing, in strong "Builders language" (Himsworth 1927-42, 12). The situation did not improve much over time. On $10^{\text {th }}$ October 1930 he records that he called at 2.15 in time to stop the men pulling to pieces masonry almost six feet by four feet high overlooking the Don and parallel with it'.

In another important entry, he wrote that on $31^{\text {st }}$ October 1928 'men were digging out the remains of a furnace, said by one of them to be the oldest in Sheffield' (Himsworth 1927-42, 9; JWM n.d.; Figure 2.18). The significance of this account is twofold. First, the men clearly knew something of the antiquity of the furnace, but demolished it anyway. And, second, this may have been the remains of a furnace whose partial destruction in 1915 had been recorded by the Sheffield Daily Telegraph and then by Wigfull in the pages of the Transac-

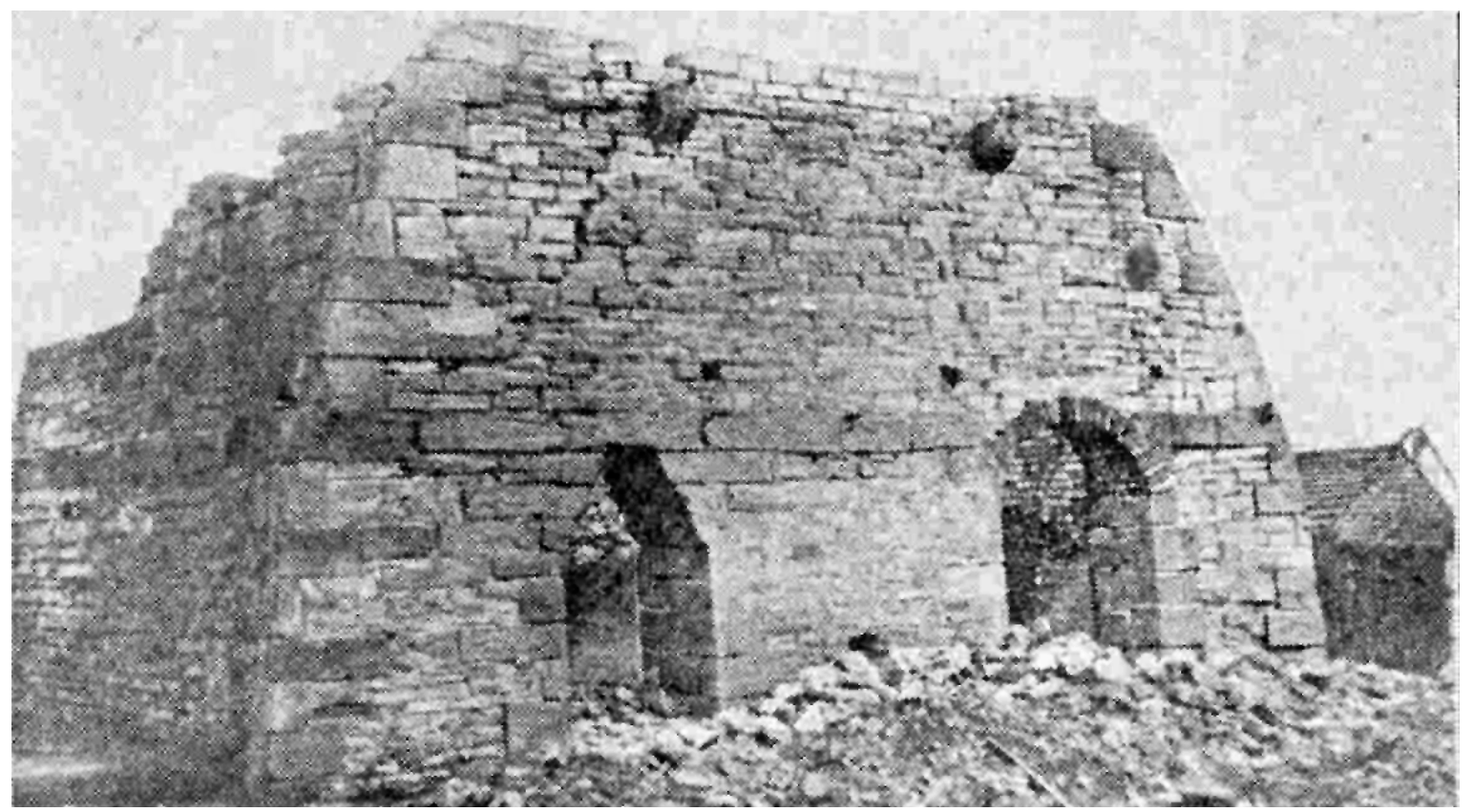

Figure 2.18: Ancient furnace on the site of Sheffield Castle. Reputed to be the oldest furnace in Sheffield, this early 20th-century photograph was included in Himsworth's typed diary. It had previously appeared in the Sheffield Daily Telegraph on $30^{\text {th }}$ March 1915. Courtesy of Museums Sheffield. 
tions of the Hunter Archaeological Society. This cupola furnace, we are told, was 'unearthed' on the castle site by 'Sheffield Corporation workmen engaged on the construction of the new road from the Great Central Station', also known as Victoria Station. It took the form of a 'square truncated mound', and was constructed from 'rubble stone with a strong course of heavy gritstone' incorporating 'slabs of the old stone from the castle' including 'portions of dressed stone and door moulds' ('Ancient furnace', 1915; Wigfull 1916, 239). A photograph of the structure published in the same issue of the Sheffield Daily Telegraph ('Sheffield's oldest furnace', 1915; and reproduced as fig. 32 in Himsworth 1927-42) shows it to have been a very substantial structure. If it had indeed been 'uncovered' during road construction, this image suggests that some significant excavation must subsequently have taken place. We are told that the furnace was located in the former premises of R\&J Smith, which are shown on the 1896 Goad Fire Insurance map of the area, with a 40in furnace cone marked in the north-east corner. This cone is not shown on the 1888 version of Goad's map, but 'part of the old castle' is noted in exactly the same place. The report in the Sheffield Daily Telegraph noted that the cone was visible in a sketch of Lady's Bridge (Winder 1907, 80); it can also be seen in an 1825 painting of the area (River Sheaf and the Shrewsbury Hospital, Sheffield; Figure 9.5). In demolishing this 'old cupola furnace' the workmen therefore erased traces of two important moments in Sheffield's history simultaneously (see Chapter 7 for how recent excavations may have recovered its traces). Wigfull (1916) ended his report by regretting the decision to abandon the scheme to cut the road through the castle site ('it is probable that some considerable remains would have been found, or even a complete plan of its arrangements laid bare') and instead to adopt one which 'involves a raising of the site rather than an excavation'. Might this be an early example where the archaeology of the site, the presence of the castle and later structures, influenced plans for development?

It was not only the workmen who were indifferent, at best, to the fragments of Sheffield's heritage being exposed, and sometimes destroyed, on Castle Hill. In September 1928, Himsworth reports that, even after substantial, visually striking, parts of the castle had been uncovered (the towers, gatehouse etc.), 'very few people were inclined to insist upon the authorities searching the ground for historic remains'. Even among those he 'thought likely' to be sympathetic, there was little appetite for recording or preserving further remains of the castle: 'everywhere the reply was, "we must clear the site quickly as possible and build a market cheaply. Conditions of trade are so bad we can neither spend time nor money and can brook no delay"' (Himsworth 1927-42, 5). In this sense, doing archaeology in Sheffield in the late 1920s was very different from today's practices, lacking the regulations that put archaeology at the heart of the planning process. Armstrong and Himsworth's presence on site seems to have been one of toleration, yet there is a great deal, perhaps a surprising amount, about their intervention on Castle Hill which finds strong echoes in contemporary, professional archaeological practice. While their records are impoverished by modern standards, they nonetheless used many of the same 'instruments' to preserve their observations - photographs, measured and sketched sections, and profiles. Himsworth's (1927-30) personal diary contains a roughly measured sketch north-south section across the site, defining and describing various layers and features ('virgin yellow clay and a few boulders - 3'6" deep'; 'remains of a tower - opp. Waingate back market entrance,' ' 9 " black occupation level', all fixed by distance from and measurement above/below the 'present road level' Figure 3.7). Armstrong's diary contains a sketch $\left(18^{\text {th }}\right.$ November 1927) of the relationship between five foundation pits and the Rotherham House Hotel, and measured sketch plans and sections of the sides of two of these 'holes' (Armstrong 1927-28, 3; Figure 2.19). In the end, Armstrong succeeded in masking the contingency that underpinned much of their work in a report that would not look entirely out of place in a modern context - an illustration of Gavin Lucas's $(2001,212)$ argument that by the 1920s and 1930s 'the standard site report was established and has changed little' since.

The quality of the recording and the 1930 publication might reasonably be explained as a product of Armstrong's considerable archaeological experience in the flint mines of Norfolk and in the caves of Derbyshire and Zimbabwe. However, a detailed study of the unpublished correspondence contained in the Museums Sheffield archive reveals it might also derive from another similarity between Armstrong's work on Sheffield Castle and modern archaeological practice. Archaeology today is very much a team effort, in terms of the numbers of professionals deployed on site and in the range of specialists called upon to plan the project and to analyse the material recovered. Although Armstrong could not rely on a team of on-site archaeologists, in developing the castle narrative, he too 'employed' a number of local specialists. Like Armstrong and Himsworth, these were men who earned their daily bread in other professions - and in many cases it was this professional expertise that Armstrong sought to exploit to enhance his understanding of the archaeology of Sheffield Castle. 

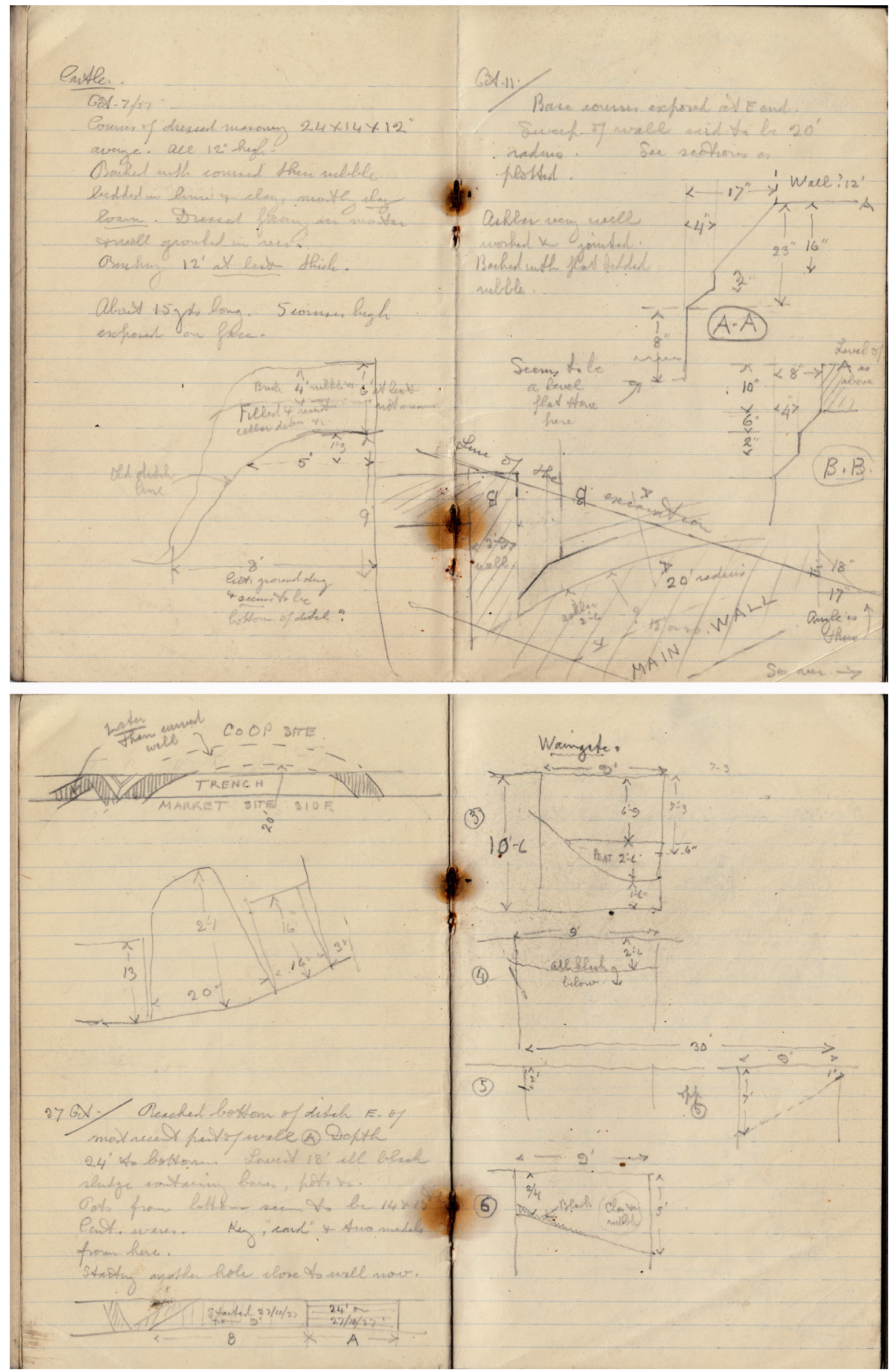

Figure 2.19: Sketch plans, profiles and excavation notes in Armstrong's on-site diary. Here he records the discovery of the monumental gatehouse and the bottoming of the moat, and provides sections through the moat as it passed Waingate. Courtesy of Museums Sheffield. 


\section{The finds specialists}

Joseph Baggaley was curator of Sheffield City Museum from 1928, and he seems to have had a very good working and (to judge from the tone and content of their correspondence) personal relationship with Armstrong. Although he also wrote on other aspects of the archaeology of the Sheffield region, particularly various Bronze Age finds (e.g. Baggaley 1938), Baggaley's specialism was in numismatics. On $9^{\text {th }}$ May 1930 he wrote to Armstrong to provide details (dates, denominations etc.) on the coins found at the castle, some of which were in the museum, having formed part of a 1929 exhibition entitled 'Old Sheffield', while others were at 'the Brightside \& Carbrook stores', perhaps in the 'cabinet of relics' on permanent view in the new premises on Exchange Street (Baggaley 1930a; Anon. 1969, 11). This information appears, almost verbatim, in Armstrong's 1930 publication, with the additional information that the Keeper of Coins at the British Museum had been able to identify 12 brass, coin-like, objects (presumably including the eight 'Elizabethan' brass counters referred to by Baggaley) as 'sixteenth century counters ... [eight of which] are inscribed in Tudor lettering "Ave Maria Gracia [sic - surely 'Gratia'] Plena", with the abacus in the centre. On the reverse are emblems of the Apostles, or a fleur-de-lys design' (Armstrong 1930, 25; Moreland and Gorman 2019; see Chapter 6 for further discussion).

Another of the specialists to whom Armstrong turned in pursuit of further detailed information from the castle finds was Frederick Bradbury, co-owner of Thomas Bradbury \& Sons, the famous Sheffield silversmiths and silver platers. Bradbury wrote to Armstrong on $11^{\text {th }}$ June 1930, returning ' 4 buttons' (although he goes on to talk about five; Figure 2.20). He had concluded that a pair of sterling silver buttons were 'in all probability' from 'the coat of some officer or gentleman' (Bradbury 1930a; nos 7, 8 on Armstrong's plate II; Figure 2.21), while a smaller one was 'probably used as a waistcoat button' (no. 10). Believing that they had been produced 'around the middle of the 17th century', he suggested to Armstrong that, given their composition, they 'would not have been thrown into the moat in a haphazard way along with various odds and ends of discarded garments' but rather 'may have belonged to some of the soldiers or civilians taking part in the fighting outside the castle' (Bradbury 1930a). The other two buttons (probably nos 6, 9) were bronze but, applying a social/military hierarchy to them, Bradbury could not determine if they were formerly on the coats of retainers ... as they bear no evidence of an heraldic design or any other form of ornament'. He was, however, able to date one to 'the Cromwellian period' (no. 6).

Bradbury was clearly puzzled by the discovery of three silver buttons in the fill of the castle moat (remember the 'sticky black sludge') and, having reflected on the matter, wrote to Armstrong again on $17^{\text {th }}$ June 1930 with the thought that ' 200 or 300 years ago people regarded silver with a good deal of respect, the price then being high. He went on to make the kind of offer that would horrify conservators today and which certainly reflects changed priorities in our approach to artefacts: 'I had thought of just polishing the top of one of those silver buttons for you, as there are a pair. Would you like me to do this? if so, kindly send one to me and I will have it done for you' (Bradbury 1930b)!

The depth of Bradbury's interest, and expertise, can be gauged from the fact that he returned to the buttons once again, getting them back from Armstrong and, as reported in a letter of $8^{\text {th }}$ July 1930, subjecting them to 'a longer and more exhaustive examination'. That examination involved the deployment of unspecified techniques to determine their metallurgical composition, with unfortunate consequences for the smallest of the buttons (presumably that which he had earlier identified as being from a waistcoat; Bradbury 1930c). He was able to determine that it was 'partly silver, possibly 50\%', but 'in taking the test' the button came apart, 'a small section having flown away which I failed to recover. He was also able to show that the other two buttons only had a silver content of between $25 \%$ and $50 \%$, and suggested that, as long as the finished object 'had a whitish hue they [people in the past] were not very particular concerning ingredients'. He went on to note that there was 'certainly no plating of any description'.

What especially interested him, however, were the six pins also sent to him by Armstrong, which 'are nearly pure gold, i.e. either 18 or 22 carat (a most interesting discovery)' (Bradbury 1930c). He returned at the end of this letter to say 'I wonder how you managed to acquire the tiny and interesting gold pins' - presumably considering the less-than-optimal conditions for archaeological recovery on the construction site. These are probably the pins illustrated as no. 7 on plate III of Armstrong's 1930 publication (Figure 2.22), and Armstrong, perhaps not sharing Bradbury's special interest, provides only the following additional information: 'Pins, of drawn gold, heads formed of coiled wire' (Armstrong 1930, 27). Some pins from the castle site survive in the Museums Sheffield (2019b) collection, but these are copper alloy (Chapter 6, Section: Domestic and personal items). Given his knowledge and experience, it is unlikely that these are the ones Bradbury described as 'nearly 


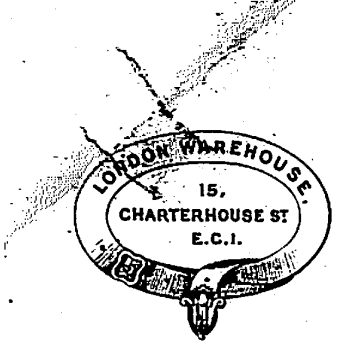

TELEGRAPHIC ADDRESSES: "BRADBURY, SHEFFIELD":

"SILVIUM LONDON."

TELEPHONES

SHEFFIELD,20514. LONDON;HOLBORN.1381

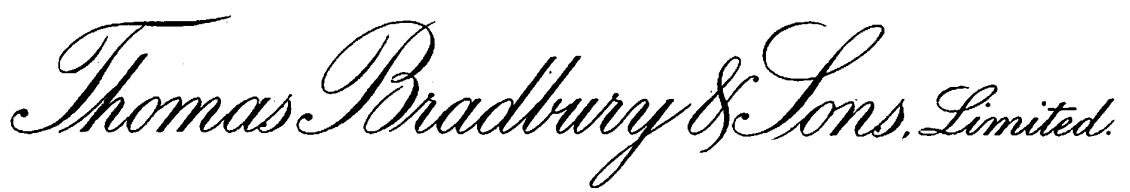

Direndel Coreet.

\section{A. Iesile Armstrong Esq., 52, Warburton Street, Stockt on Heath, \\ Warringtor.}

Dear Armstrong,

I return the 4 buttons herewith.

Three of them are of sterling silver. The pair $1^{n}$ across, one of which has the oje missing, were in all probability attached to the coat of some officer or gentleman of rank, likewise the other small specimen just under $\frac{8}{4}^{\prime \prime}$, this was probably used as a walstcoat button.

I take 1t, that being of precious metal they would not have been thrown into the moat in an haphazard way along wilh various other odds and onds of discarded gaments. It is just possible they may have belonged to some of the soldiers or civilians taking part in the fighting outside the castle or in an attack.

I should tate these silver buttons as heving been produced about the indale of the lith century.

of the other two, formerly a pair, these are composed of bronze.

conta.

Figure 2.20: Letter from Frederick Bradbury to Leslie Armstrong, $11^{\text {th }}$ June 1930 (page 1). Here Bradbury informs Armstrong about his analysis, and interpretation, of buttons found in the castle moat. Courtesy of Museums Sheffield. 


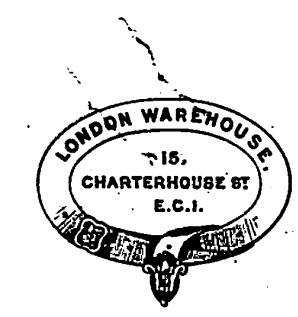

TELEORAPHIC ADDRESSES: BRADBQURY, SHEFFIELD' "SILVIUM LONDON."

TELEPHONES SHEFFIELD, 205 I LONDON,HOLBORN.138T
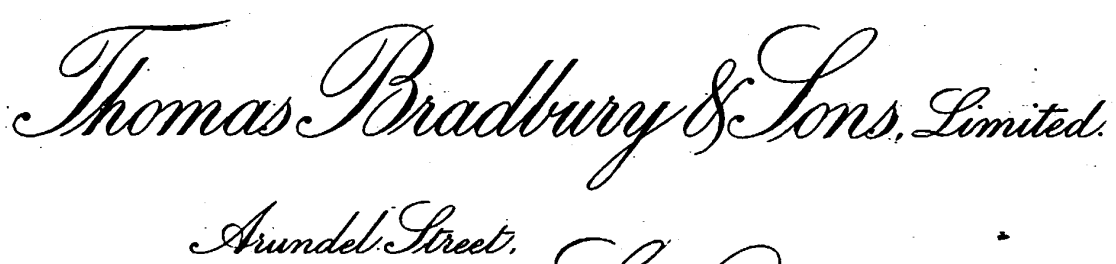

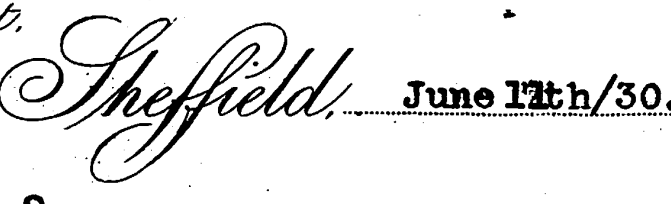

The one with decoration thereon consisting of

a round volute engraved centre ornament is typical of the Cromwellian period. Whether these two buttons were formerly on the coats of retainers or not it would be difficult to state, as they bear no evidence either of an heraldic design or anj other form of ormament, as would probably have been the case had they been used either on a military unifora or hunting equipment.

$$
\text { Yours very truly, }{ }_{\text {bred }} \text { Bradbery }
$$

Figure 2.20 (continued): Letter from Frederick Bradbury to Leslie Armstrong, $11^{\text {th }}$ June 1930 (page 2). Courtesy of Museums Sheffield. 

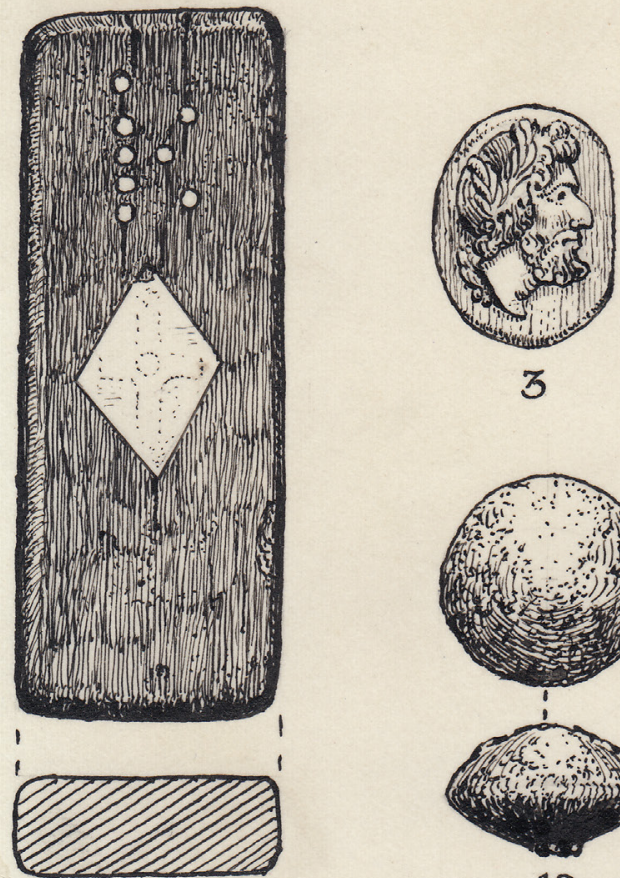

3

1
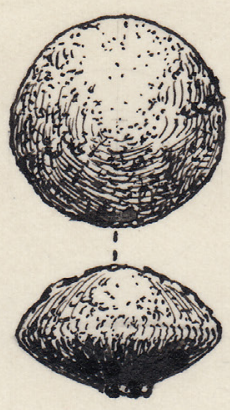

10

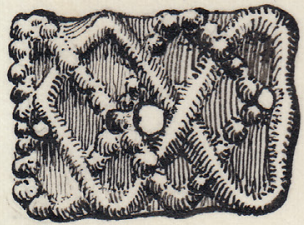

5
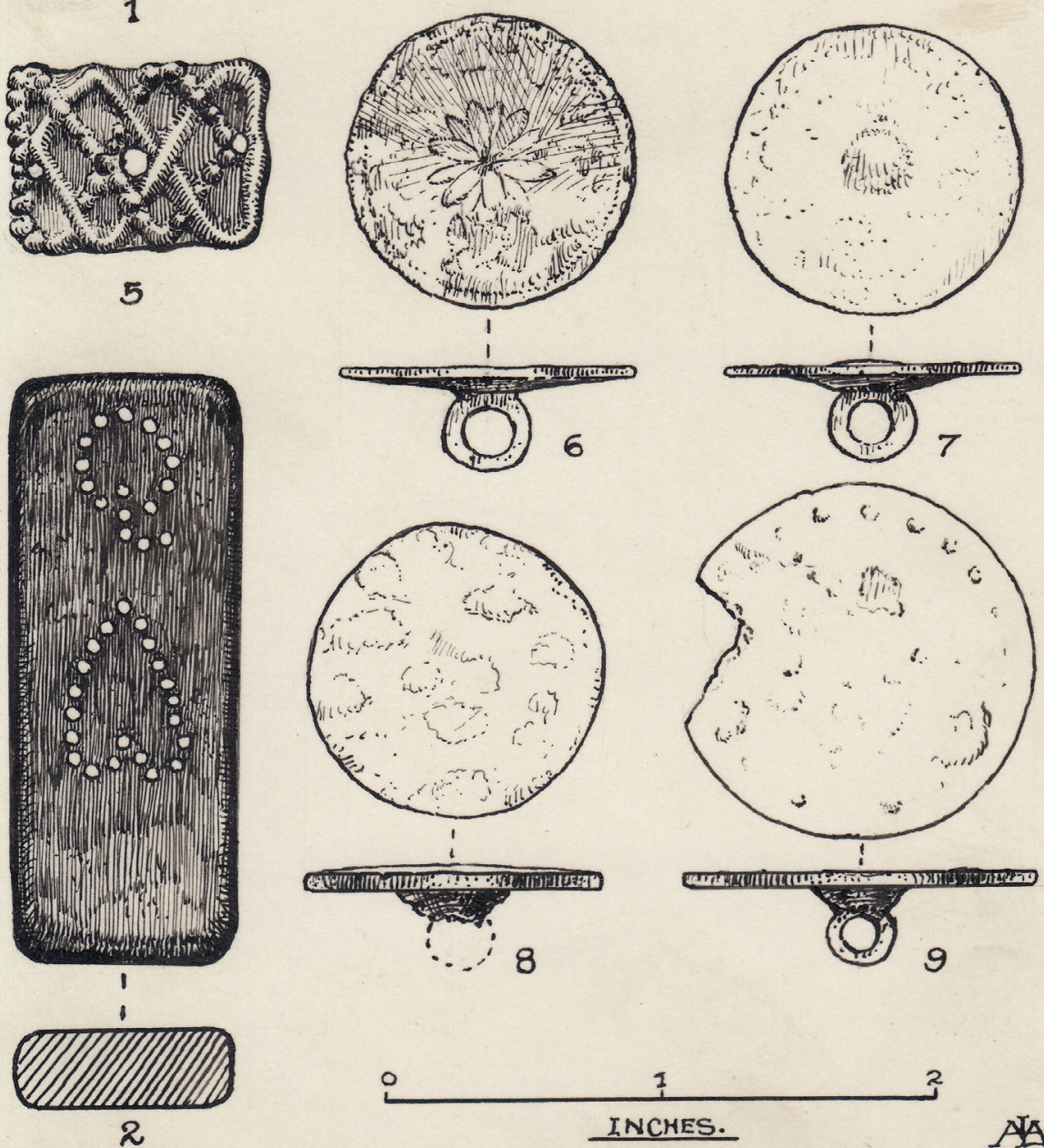

A

Figure 2.21: Plate II from Armstrong's 1930 paper on Sheffield Castle. This shows the 'playing card' he recovered from the moat (1) and a similar item shown to Armstrong by a local boy (2; see Chapter 6, Section: Domestic and personal items), a wooden/brass crucifix, a brooch mount, and various buttons examined by Frederick Bradbury (see also Figure 2.20). Hunter Archaeological Society. 


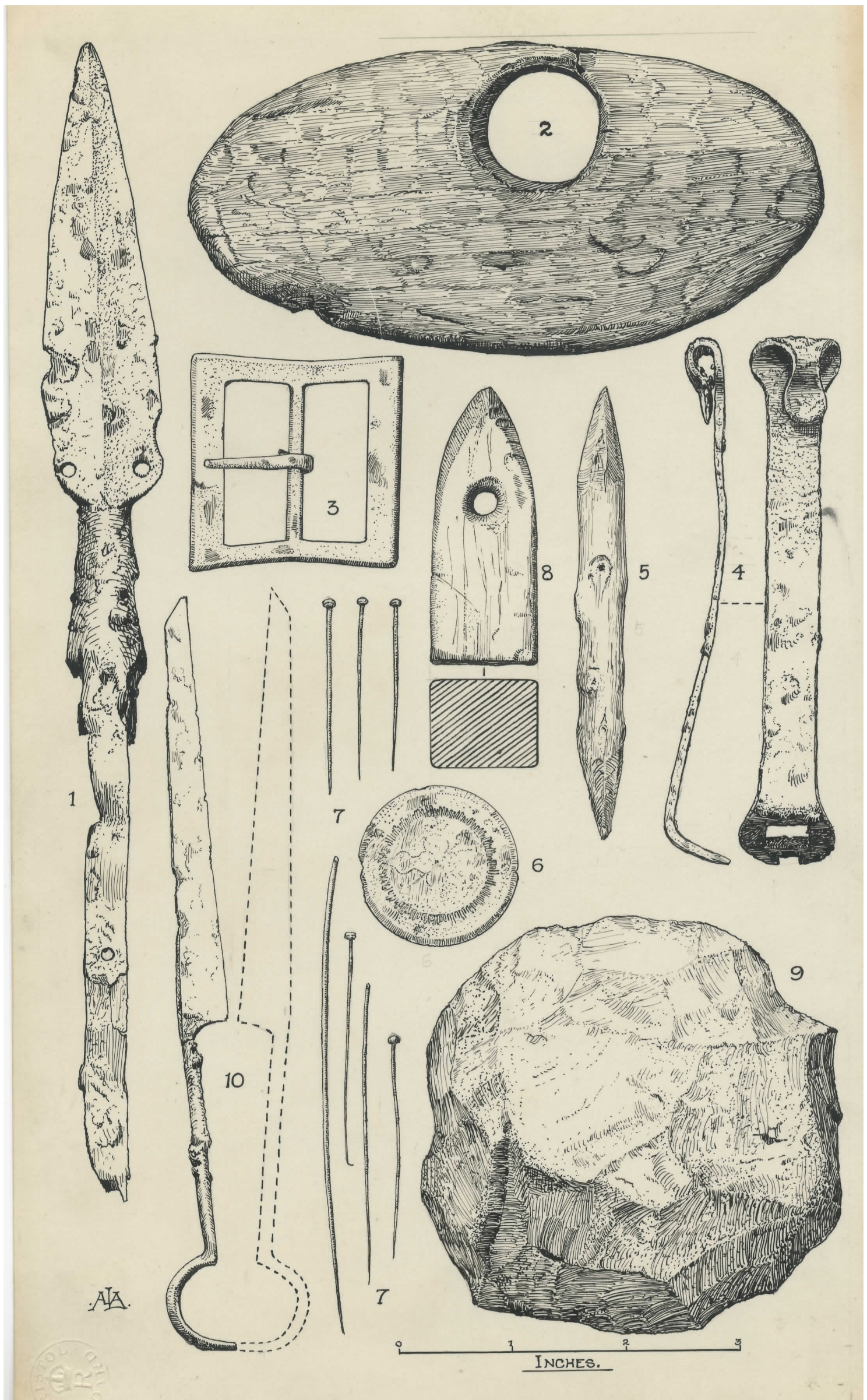

Figure 2.22: Plate III from Armstrong's 1930 paper on Sheffield Castle, illustrating a spearhead, saddler's palm guard, button, pins, buckle, shears, whetstone, textile-working implements and a padlock slide key, misidentified by Armstrong as a 'probable cheek piece from a horse's bit. Hunter Archaeological Society. 
pure gold', and we should note that Armstrong provides another illustration of 'gold pins ... from the Ditch' (his fig. 16), some of which look more like those currently curated by Museums Sheffield.

One of the objects which had captured the attention of both Armstrong and (he hoped) of the construction workers was, as we have seen, a large key 'neatly ornamented and of elegant form', which was 'quite free from rust' and would 'originally have almost the appearance of silver' (Armstrong 1927b; 1930, plate I (no. 1); Figure 2.23). To identify its composition, Armstrong turned to specialists at the University of Sheffield. William George Fearnsides, Professor of Geology, and Cecil Henry Desch, Professor of Metallurgy, examined the key and determined that it was 'almost pure block tin' (Armstrong 1927b; block tin is pure tin - as opposed to tin plate - with only very small quantities of impurities). Their contribution was not only the start of the University's engagement with the archaeology of the castle, which continues to this day, but was part of a long-term relationship with Armstrong, Fearnsides helping him in his work at Creswell Crags (Armstrong 1932, 331; 1942, 50), and Desch with the analyses of bronze axes and palstaves which Armstrong (1926b, 164) oversaw on behalf of the 'British Association Committee on the Distribution of Bronze Age Implements'. Their involvement highlights access to specialists who combined their practical skills and knowledge with a passion for understanding the past. Desch's archive in the University of Sheffield's Special Collections contains information on his work with the 'Sumerian Committee of the British Association' in their efforts to determine the origins of the copper used by the Sumerians, as well as his correspondence with some of the world's leading archaeologists - including V. Gordon Childe, Harold Peake, Winifred Lamb, Cyril Fox, and Leonard Woolley (Anon. n.d. (a)). Similarly, not only was Bradbury one of Sheffield's leading silversmiths; he was also author of A History of Old Sheffield Plate (1912), the fundamental work on the subject, elected as a Fellow of the Society of Antiquaries, and an associate member of the British Archaeological Association from 1913. The firm's catalogue, c.1920, lists not only the usual cream jugs, sauce boats and coffee sets but also illustrates historic cutlery for sale, including 'reproductions of Roman Spoons found while excavating Ancient Camps in England' and 'The Bath Spoon ... from a Roman Original found in the District', showing how his interest in the past informed his own craft practice. In a letter to the editor of the Sheffield Daily Telegraph published on Wednesday, $19^{\text {th }}$ October 1927, he wrote about how the discoveries on the ongoing excavations at the castle reminded him of the great feasts once held there, noted (again linking his craft with his historical interest) that the 'display ... of silver plate and pewter on the "Dressors" must have been prodigious', and asked 'where has it all gone?'

Drawing on his professional experience and knowledge of local history, Himsworth was another specialist contributor to the analysis of artefacts from Sheffield Castle. Reports in local newspapers make clear the depth of his knowledge, which was never merely 'local', with his public lectures ranging from 'Florentine guilds' $\left(9^{\text {th }}\right.$ December 1924$)$ to 'Beauty and interest in North-East Notts' $\left(16^{\text {th }}\right.$ November 1931$)$. A two-page note written to Armstrong on $29^{\text {th }}$ May 1930 illustrates how he brought this knowledge to bear on some of the artefacts from the excavations. It concerns single blades from two different pairs of shears (no. 9 on plate I (Figure 2.23) in Armstrong's 1930 paper, dated to the 16th century from 'its position in the ditch', and no. 10 on plate III (Figure 2.22), 'from the lower levels of the ditch' and dated to between the 13th and 15th centuries). Having outlined the basic dimensions and appearance, one set being more 'gothic' in shape, Himsworth (1930c) then described how he cleaned (!) 'until the bright steel appeared', allowing him to observe that they were composed of solid steel, not 'iron welding, with steel facing for the cutting edge, as has been said is the case in this period work'. His tests demonstrated the same 'steel hardness all over the blade', though the material itself was 'very coarse' - a product, he thought, of 'great variation in or lack of homogeneity in the steel' rather than of overheating in forging. He concluded that 'the general shape, lightness with strength and the proportions of both [examples] compare favourably with the best modern productions' (also Armstrong 1930, 26-7, for how this memo was used in the final excavation report).

Himsworth seems to have examined a range of objects, supplying Armstrong with a stream of information in the build-up to the publication of the excavation report. In a letter of $13^{\text {th }}$ May 1930, in which he recorded the return of various metal objects ('from the Co-op collection'), ${ }^{9}$ offering some thoughts on conservation, Himsworth (1930b) told Armstrong that 'it would be a very congenial task to describe the knives as you suggest' (emphasis added; Figure 2.24; also Himsworth 1930d). In his 1935 lecture he recounted that Armstrong 'gave [him] the job of preparing a detailed description' of the knives found during the excavations (Himsworth $1935,7)$, which appears at the end of Armstrong's $(1930,25-6)$ report on the excavations. In his '500 years of

9 'Iron key, 2 small knife blades, 1 large knife blade, paper of 4 pins, 2 large flat buttons, 1 small round bean shaped button.' 


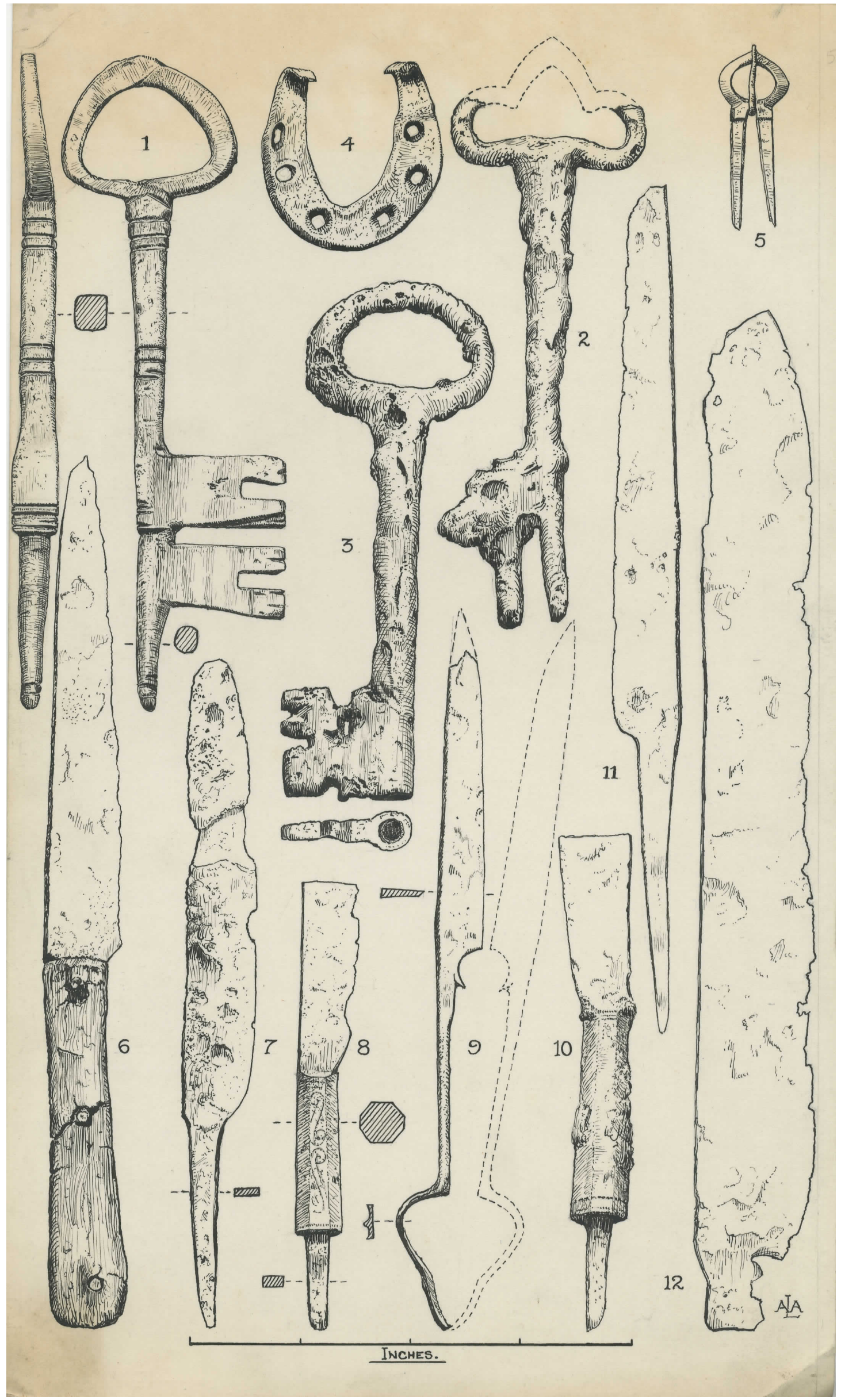

Figure 2.23: Plate I from Armstrong's 1930 paper on Sheffield Castle, illustrating some of the other significant finds, including keys, knives and shears. Hunter Archaeological Society. 
10 13. (Promial number)

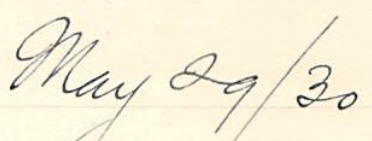

Two freces of ahear style sersar, notanig uf ne lelade unth shante and hant of bour.

Iotal length of the tor heeces $=6 \frac{3}{8}$ inches.

In cleaving away monstution and must, exterswe fatches

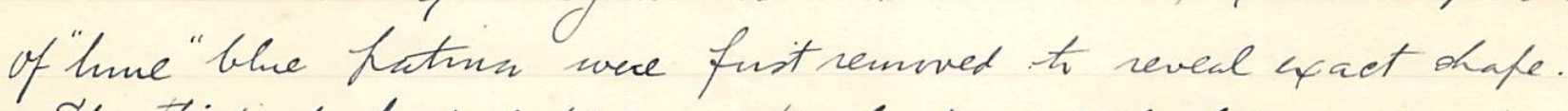
The thickest hant of blade is the back, a little keluw where the blade Hists foins the shank, and is $3 \mathrm{M} / \mathrm{M}$. The undth of blade at the same flace is $\frac{Y}{16}$ " ov $11 \mathrm{M} / \mathrm{M}$ and the bevel on the cuttungedge here is $4 M / M$. troad(micherded in the IIM/M)

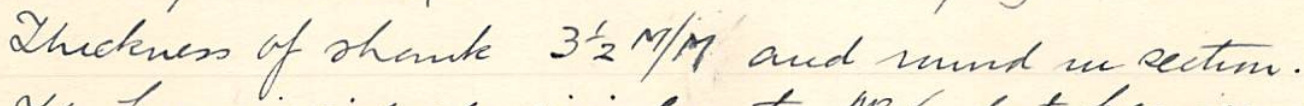

The bow is ridged siniluw to 106 but heaver and binflew in sectim and $3 \mathrm{M} / \mathrm{M}$ thotest hat. The fow whew cmiflete was horbably sund mi cuttene, not giother." 106 biw is flat an the siside; and on the autride, a reed, udge a nember surs unid it with a hollow on either arle of it. 1913? bow is hrpanidal on section. The base of fhymand benig the flat inside and the tow sides slightly munded a full! The apex then foums the center vidge

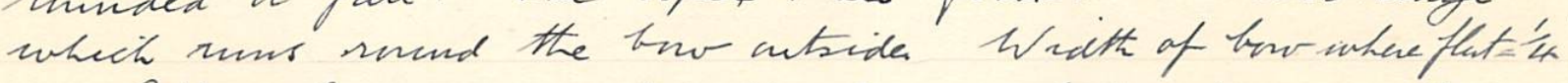
After cleanmig untel the bight sted afpeared, there is no endence of im woddrig, usth sted facmin for the cuttury edge, as has nea said is the case mo the lourd unk. Iny ofminis that torls of sueh suade hoofntions.

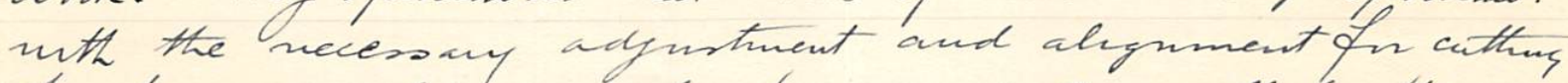
huifises culd sut he hroduced so soll hy the use of the tho metuls as if only soled ated were nsed.

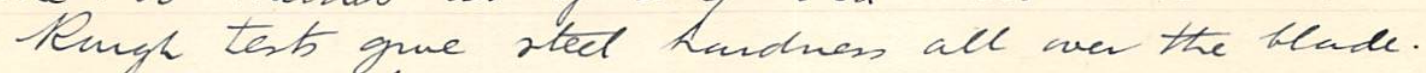
The ingitt frocture stumin where thade tas been hroken finm shank (enderthy sunce the astucle was discuered) otwos ven crarse stucture of material.

Figure 2.24: Note written by Joseph Himsworth to Leslie Armstrong in late May 1930 (page 1). In this Himsworth provides detailed metallurgical information on the finds that he had been analysing. Courtesy of Museums Sheffield. 


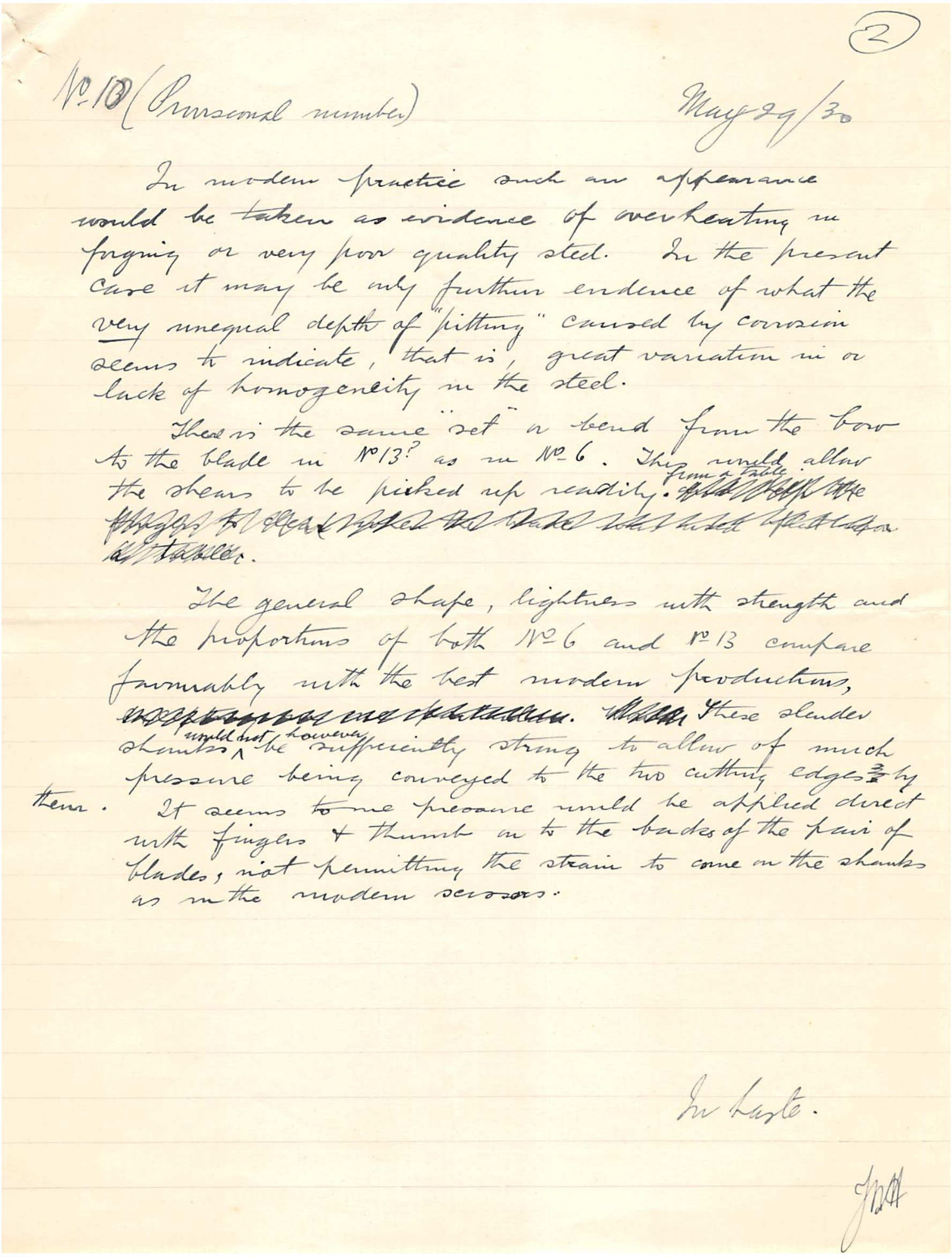

Figure 2.24 (continued): Note written by Joseph Himsworth to Leslie Armstrong in late May 1930 (page 2). Courtesy of Museums Sheffield. 
Sheffield trade and Sheffield castle' lecture, Himsworth $(1937,3)$ reminded his audience that 'one knife found in Sheffield Castle moat had damaskening in gold and had a chased, that is, a punched design upon it' (also Armstrong 1930, 25-6 and no. 8 on plate I; Figure 2.23). Himsworth (1930b) clearly looked at other objects too - the letter of $13^{\text {th }}$ May contains his thoughts on 'a small round bean shaped button', and Armstrong's paper includes his description and analysis of one 'half of shear style scissor' (Armstrong 1930, 27, also plate III (no. 10)). He was also keen to do more; he finished his letter by assuring Armstrong '[i]t is a pleasure - so please don't hesitate to give me other matters to deal with when I can be of use' (Himsworth 1930b). In his analysis of these artefacts, Himsworth was encountering the archaeological traces of craft working, and of the common man that he seems to have been so interested in; as we will see in Chapter 6, the traces of the servants, craftworkers and merchants who supplied and facilitated the daily routines of the castle emerge very strongly from the wider material record.

It is as well that Armstrong engaged these specialists, as our examination of the archives revealed that some artefacts recovered from the castle site have sadly been subsequently lost, and so the accounts in his 1930 paper and in the archived correspondence provide the only surviving records. The most dramatic factor in this depletion was the bombing of Sheffield in December 1940, causing the loss of those items at the Brightside and Carbrook Co-op Society building, which was destroyed (Himsworth 1927-42, 21; 1944, 1; Figure 4.1). As these items were on public display, it seems likely that they included some of the more significant and visually striking finds. The Society's report for 1969 describes 'a cabinet of relics (cannon balls, tobacco pipes, leather, sword pieces etc.)' having formerly been on view there (Anon. 1969, 11), but there is no surviving inventory of what this contained. Lost in the bombing may have been some of the items illustrated by Armstrong in his 1930 paper that could not be traced in the archive, including some of the gold pins, two leather shoe soles (nos 40,42) and a shoe vamp (no. 142) (Mould 2017a). The written accounts of the 1927-30 excavations also document the removal of items from the site. For example, in a handwritten amendment at the end of the typed version of his diary, Himsworth $(1927-42,21)$ notes that he then had 'a few objects taken from the moat in his possession viz: an early shoe sole and several blades depicted by Armstrong in his report', all of which seem to be missing from the museum archive, and may never have been deposited. His diary also records his acquisition from the excavations of 'an antler and Tudor shoe sole', and 'some fragments of Midhope pottery' (Himsworth $1927-42,3,11,39)$. Some items found in the 1920s were even given away, including 'a terra-cotter ornament dug up on the site' presented by the Clerk of Works, Reg Loughran, to Himsworth's mother when she visited the excavations in November 1928 (Himsworth 1927-42, 9), while one of Himsworth's relatives has told us that he had 'bestowed a box of archaeological treasures' on her brother (Hutten pers. comm.). In sum, while there was undoubted concern to see the finds from the castle recorded, there was not necessarily an expectation that the City Museum was the appropriate place for all of them to end up.

\section{The enduring legacy of Leslie Armstrong}

This correspondence between Armstrong and a range of specialists highlights his pivotal role in the accumulation of knowledge about Sheffield Castle, and it was to him that requests for information were directed. For example, the secretary of the Brightside and Carbrook Co-op wrote to him to ask for help with the souvenir brochure planned to mark the opening of their new premises on the castle site (Forster 1928; 1929). Despite the growing importance of Himsworth in recording the castle excavations, it seems that in this respect not much changed even after Armstrong left Sheffield for a new job in Warrington (Cheshire). Thus, W. G. Davies (1930a), the City Architect, wrote to him in Warrington on $20^{\text {th }}$ June 1930 providing a 'ground floor and foundation plan of the new market with the vestiges of walls remaining of the Sheffield Castle. He wrote again on $12^{\text {th }}$ August providing a plan 'showing the new market with relation to the surrounding streets at present, and before the street widening' (Davies 1930b). It is likely that Armstrong asked for this information to assist with the preparation of the excavation report. He received the proofs of this from the publisher, J. W. Northend, on $30^{\text {th }}$ August, with a request, among other things, to provide figure numbers and captions, and with the (very familiar) warning that 'publication is now being held up for this article' (Northend 1930b). So, when Davies (1930c; see also 1930d) wrote to him again on $17^{\text {th }}$ November 1930 to provide 'a tracing shewing a further section of walling which has been uncovered by the City Engineer's workmen when excavating the new Road, ${ }^{10}$

${ }^{10}$ Significantly, Davies also told him that '[a]t the corner of Lady's Bridge, a foundation stone was discovered in which was a cavity containing brown fragments of paper, which has also been preserved'. 
it would seem likely that this was to inform some other project. Correspondence between Armstrong and Northend provides us with an insight into what this might have been.

On $31^{\text {st }}$ October 1930 Himsworth wrote to Armstrong telling him that the Hunter report was 'easily the most important local thing of its kind for many years', and urged him to give it a 'wider circulation' (Himsworth 1930c). ${ }^{11}$ It is not clear that Armstrong needed this encouragement; he had already asked Northend for 200 copies of the Transactions report, and his archived correspondence has numerous replies, and thanks, from those to whom he had sent them (Northend 1930b; Edwards 1930). Nevertheless, on $13^{\text {th }}$ November, he wrote to Northend with an idea for a book on Sheffield Castle. Northend's reply of $22^{\text {nd }}$ November provides more detail on what the proposed book was to contain: Armstrong's Transactions paper, an 'additional chapter', and 'Mr. Drury's article on the "History of the Castle"' - '500 copies, bound full red cloth, stiff boards' (Northend 1930c). ${ }^{12}$ Unfortunately for Armstrong (and us!), Northend (1930c) added that, while they would have been pleased to print it, they 'cannot undertake the financial responsibility of publishing the book'. And there the matter seems to have ended. The point here, however, is that, although not present in Sheffield while the last phases of these interventions on the castle site were taking place, it was to Armstrong that people turned when they wanted something written on the castle. Prehistorian, and resident in Warrington, he may have been, but such was his experience and stature that Armstrong remained the person with the authority to write the 'official' narrative of Sheffield Castle, a narrative upon which (until now) all subsequent understandings have been anchored.

\section{Conclusion}

While the 1930 report on the remains of Sheffield Castle published by Armstrong is the best-known insight that we have into what was found on the site, it is clearly not the complete account, nor does it fully do justice to the circumstances of the recording undertaken. Armstrong was a very experienced excavator, and his recording methods were typical of the period, but while he was the 'great man' who provided a figurehead for the excavations it was the comparatively unknown Himsworth who was more frequently on the ground, liaising with the workmen and continuing to record what was emerging after Armstrong had moved on. While Armstrong may have been regarded at the time - and ever since - as the expert on the excavations, his interest in the site had clearly dwindled by early 1930, if not earlier, and his plans to write a book on the castle progressed no further than handwritten drafts. In fact, it was Himsworth, with his range of intellectual interests, political sensibilities and interest in hunting out the common man who kept the story of Sheffield Castle alive through his public lectures. The account presented in this chapter has only passing resemblance to the way in which early castle studies have been characterised recently, with Matthew Johnson $(2002,4)$ writing that

A generation of scholars working on castles were military men. They chose to pursue historical interests in retirement; and the obvious place to look for evidence of changing medieval techniques of warfare was the castle. Castles, then, were understood in military terms almost by definition (see also Stocker 1992).

This hardly does justice to men like Armstrong and Himsworth, whose approach was deeply embedded in local society and the urban landscape, little interested in matters of war and defensibility but concerned with local placemaking and traditions; it was this that drove them on, and, as we will see in Chapter 3, shaped the narratives about the castle that they created.

\section{Bibliography}

The full bibliography is available at the end of this volume, or at: https://doi.org/10.22599/SheffieldCastle.k.

${ }^{11}$ Note that the entry for $31^{\text {st }}$ October 1930 in the extracts from Himsworth's original diary reads as follows: ' 25 Reprints from JRW [Wigfull] to send on to ALA [Armstrong]' (Himsworth 1927-30).

${ }^{12}$ The latter is probably that published the previous year, with a comment by Armstrong, in Drury's posthumous collected essays A Sheaf of Essays by a Sheffield Antiquary. The proofs of Drury's posthumous volume survive in the Museums Sheffield archive, and were presumably supplied to Armstrong by Northend, as the publisher's stamp appears on the text (Drury 1929a). 